OPEN ACCESS

Edited by:

Alessandro Aiuppa,

University of Palermo, Italy

Reviewed by:

Taryn Lopez,

University of Alaska Fairbanks,

United States

J. Maarten De Moor,

OVSICORI-UNA, Costa Rica

${ }^{*}$ Correspondence:

Tjarda Roberts

Tjarda.Roberts@cnrs-orleans.fr

Specialty section:

This article was submitted to Volcanology,

a section of the journal

Frontiers in Earth Science

Received: 06 October 2018

Accepted: 03 June 2019

Published: 03 July 2019

Citation:

Roberts T, Dayma G and Oppenheimer C (2019) Reaction Rates Control High-Temperature Chemistry of Volcanic Gases in Air.

Front. Earth Sci. 7:154. doi: 10.3389/feart.2019.00154

\section{Reaction Rates Control High-Temperature Chemistry of Volcanic Gases in Air}

\author{
Tjarda Roberts $^{1 *}$, Guillaume Dayma ${ }^{2}$ and Clive Oppenheimer ${ }^{3}$ \\ ${ }^{1}$ CNRS UMR7328, Laboratoire de Physique et de Chimie de l'Environnement et de l'Espace, Université d'Orléans, Orléans, \\ France, ${ }^{2}$ CNRS, Institut de Combustion Aérothermique Réactivité et Environnement, Université d'Orléans, Orléans, France, \\ ${ }^{3}$ Department of Geography, University of Cambridge, Cambridge, United Kingdom
}

When volcanic gases enter the atmosphere, they encounter a drastically different chemical and physical environment, triggering a range of rapid processes including photochemistry, oxidation, and aerosol formation. These processes are critical to understanding the reactivity and evolution of volcanic emissions in the atmosphere yet are typically challenging to observe directly due to the nature of volcanic activity. Inferences are instead drawn largely from observations of volcanic plumes as they drift across a crater's edge and further downwind, and the application of thermodynamic models that neglect reaction kinetics as gas and air mix and thermally equilibrate. Here, we foreground chemical kinetics in simulating this critical zone. Volcanic gases are injected into a chain-of-reactors model that simulates time-resolved high-temperature chemistry in the dispersing plume. Boundary conditions of decreasing temperature and increasing proportion of air interacting with volcanic gases are specified with time according to an offline plume dynamics model. In contrast to equilibrium calculations, our chemical kinetics model predicts that $\mathrm{CO}$ is only partially oxidized, consistent with observed $\mathrm{CO}$ in volcanic plumes downwind from source. Formation of sulfate precursor $\mathrm{SO}_{3}$ at $\mathrm{SO}_{3} / \mathrm{SO}_{2}=10^{-3} \mathrm{~mol} / \mathrm{mol}$ is consistent with the range of reported sulfate aerosol to $\mathrm{SO}_{2}$ ratios observed close to crater rims. High temperature chemistry also forms oxidants $\mathrm{OH}, \mathrm{HO}_{2}$, and $\mathrm{H}_{2} \mathrm{O}_{2}$. The $\mathrm{H}_{2} \mathrm{O}_{2}$ will likely augment volcanic sulfate yields by reacting with $\mathrm{SO}_{2(a q)}$ in the cooled-condensed plume. Calculations show that hightemperature $\mathrm{OH}$ will react with volcanic halogen halides $(\mathrm{HBr}$ and $\mathrm{HCl})$ to yield reactive halogens $(\mathrm{Br}$ and $\mathrm{Cl})$ in the young plume. Strikingly, high-temperature production of radical oxidants (including $\mathrm{HO}_{x}$ ) is enhanced by volcanic emissions of reduced gases ( $\mathrm{CO}, \mathrm{H}_{2}$, and $\mathrm{H}_{2} \mathrm{~S}$ ) due to chemical feedback mechanisms, although the kinetics of some reactions are uncertain, especially regarding sulfur. Our findings argue strongly that the chemistry of the hot near-source plume cannot be captured by equilibrium model assumptions, and highlight the need for development of more sophisticated, kinetics-based, high-temperature CHONS-halogen reaction models.

Keywords: thermodynamic equilibrium model HSC, combustion kinetics model chemkin, high-temperature, magmatic gas emission, at-source primary sulfate, volcano plume, volcanic eruption, sulfuric acid 


\section{INTRODUCTION}

Volcanoes release gases and aerosols to the atmosphere through both quiescent (passive) degassing, and effusive and explosive eruptions. Volcanic emissions of $\mathrm{SO}_{2}$ to the stratosphere are well known to impact climate through the atmospheric oxidation of $\mathrm{SO}_{2}$ to form radiatively active sulfate aerosol particles. In fact, volcanoes release a wide range of highly reactive gases that can impact atmospheric composition and climate. Volcanic bromine and chlorine emissions undergo plume atmospheric chemistry that can destroy both tropospheric and stratospheric ozone. In descending order of typical abundance (which varies with volcano setting, magma redox conditions, and eruptive style) volcanic gas emissions consist of: $\mathrm{H}_{2} \mathrm{O}, \mathrm{CO}_{2}, \mathrm{SO}_{2}, \mathrm{HCl}$, $\mathrm{HF}, \mathrm{H}_{2} \mathrm{~S}$, OCS, $\mathrm{CO}$, and $\mathrm{HBr}$, as well as other trace species e.g., metals. Observations of volcanic plumes identify several additional species (e.g., $\mathrm{NO}, \mathrm{NO}_{2}, \mathrm{HNO}_{3}, \mathrm{BrO}, \mathrm{OClO}, \mathrm{SO}_{4}{ }^{2-}$, $\mathrm{HO}_{2} \mathrm{NO}_{2}$, and $\mathrm{H}_{2} \mathrm{O}_{2}$ ), (Allen et al., 2000; Mather et al., 2004b; Bobrowski et al., 2007; Oppenheimer et al., 2010; Carn et al., 2011; Martin et al., 2012; Kern and Lyons, 2018). These species are formed by oxidizing chemical reactions as the magmatic gases mix with air, first at high temperatures near to the source and then at low temperatures as the cooled plume disperses further into the background atmosphere. Numerical models of low-temperature atmospheric chemistry of the plume have been developed (e.g., Bobrowski et al., 2007; Roberts et al., 2009; von Glasow, 2010; Jourdain et al., 2016) that are able to reproduce some - but not all - of these observed oxidized species. This points to an important role of high-temperature chemistry. Current approaches apply thermodynamic equilibrium models to represent the high-temperature chemistry of the near-source plume (e.g., Gerlach, 2004; Martin et al., 2006). However, thermodynamic equilibrium calculations may be misleading if the chemistry is limited by kinetics (rates of reactions) in the rapidly cooling volcanic gas and air mixture within seconds of emission. Here, a chemical kinetics approach is developed to simulate the time-varying chemical processing of $\mathrm{C}-\mathrm{H}-\mathrm{O}-\mathrm{S}$ gases in the hot near-source plume on its release and mixing with background air.

\section{High-Temperature Products in Volcanic Plumes: Observations and Modeling}

Observational evidence for the high-temperature production of oxidants in volcanic plumes includes $\mathrm{SO}_{x y}, \mathrm{HO}_{x y}, \mathrm{NO}_{x y}$, and rapid formation of reactive halogens. Sulfate-rich aerosols have been observed at the crater-rim or in very neardownwind plumes of many volcanoes (exception: volcanic domes), Table 1. Sulfate is reported relative to co-measured $\mathrm{SO}_{2}$ which serves as a convenient yet only approximate plume tracer, allowing observations to be normalized for dilution effects. The sulfate: $\mathrm{SO}_{2}$ ratios typically range from 0.00002 up to around $0.01 \mathrm{~mol} / \mathrm{mol}$, Table 1 and references therein. Many of the ratios are too high to be explained by atmospheric oxidation of $\mathrm{SO}_{2}$ at low-temperatures on the plume transport timescale of seconds to minutes (e.g., Galeazzo et al., 2018). Instead, the observations indicate a sulfate-rich aerosol formed very close to source. One hypothesized pathway to its formation is high-temperature oxidation of a small fraction of $\mathrm{SO}_{2}$ in the near-source plume to produce sulfate precursor $\mathrm{SO}_{3}$ (Allen et al., 2000). For volcanic domes, sulfate formation may be enhanced by circulation of air inside the dome (Zelenski et al., 2015). The range in observed $\mathrm{SO}_{4}{ }^{2-}: \mathrm{SO}_{2}$ indicates variability in the near-source sulfate formation processes at different volcanoes, as well as possibly some measurement uncertainty. In all cases sulfate contributes a minor fraction to the total sulfur emission that is typically dominated by $\mathrm{SO}_{2}$ and $\mathrm{H}_{2} \mathrm{~S}$ (the proportion depending strongly on magma redox conditions; Oppenheimer et al., 2014). Nevertheless, at source (or so-called "primary") volcanic sulfate is critical to plume processes such as multi-phase halogen reactions (discussed further below) and acts as a condensational sink that can inhibit new particle formation (Sahyoun et al., 2019).

There exist few measurements of volcanic $\mathrm{HO}_{x y}$. Carn et al. (2011) report in-cloud processing of $\mathrm{SO}_{2}$ from the Huila volcanic plume by $\mathrm{H}_{2} \mathrm{O}_{2}$, with plume $\mathrm{H}_{2} \mathrm{O}_{2}$ abundance elevated above background by about 0.5 ppbv. This volcanic $\mathrm{H}_{2} \mathrm{O}_{2}$ might have

TABLE 1 | Observational evidence for at-source sulfate aerosol in volcanic plumes.

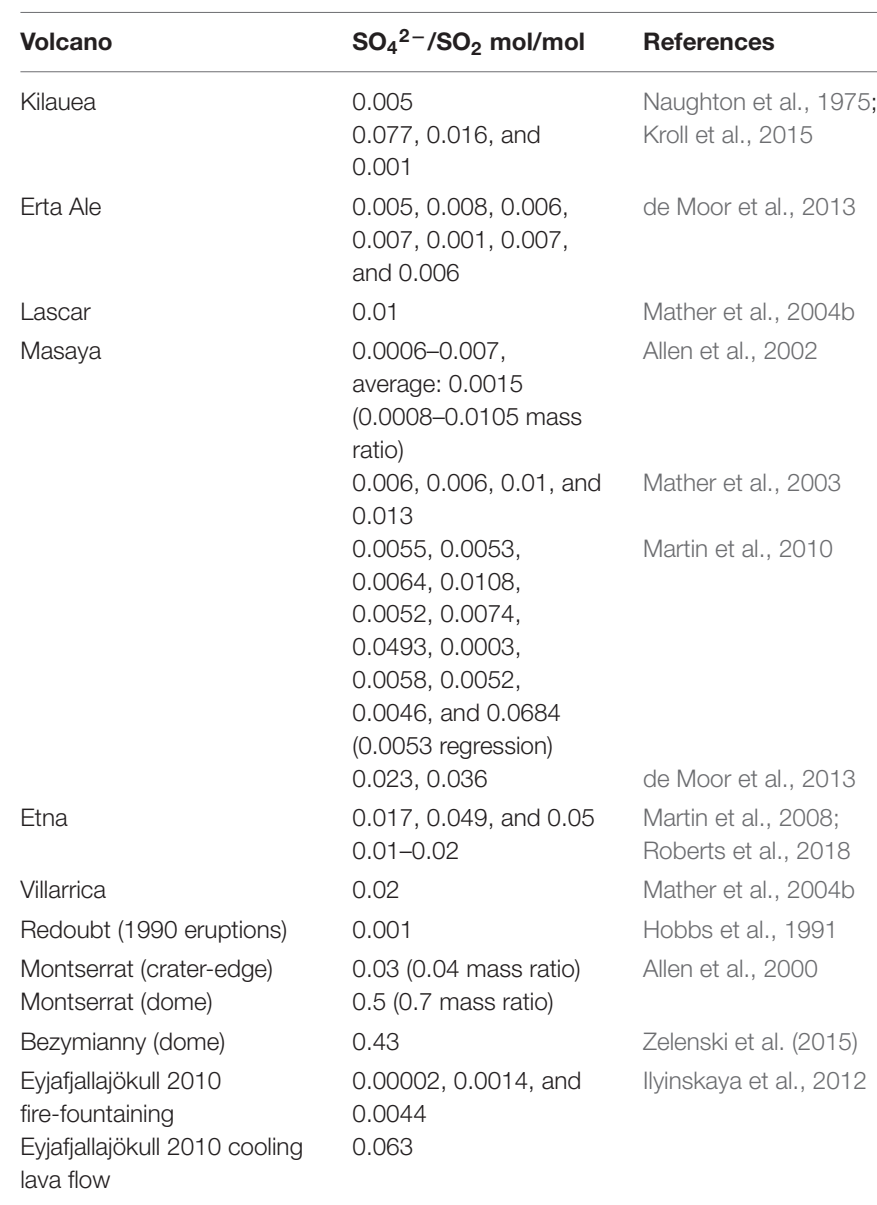

Lascar and Monsterrat mass ratios were converted into molar ratios assuming masses of $\mathrm{SO}_{4}$ and $\mathrm{SO}_{2}$. 
originated from the self-reaction of volcanic $\mathrm{HO}_{2}$. Oppenheimer et al. (2010) measured elevated $\mathrm{HO}_{2} \mathrm{NO}_{2}$ in the (cooled and dilute) Mt Erebus plume where the cold Antarctic atmosphere likely contributed to its thermal stability. $\mathrm{HO}_{2} \mathrm{NO}_{2}$ is formed by the reaction of $\mathrm{HO}_{2}$ with $\mathrm{NO}_{2}$ therefore its presence provides evidence for volcanogenic sources of both $\mathrm{HO}_{x}$ and $\mathrm{NO}_{x}$. Volcanogenic $\mathrm{HO}_{x}$ has also been observed by a chance encounter of an instrumented aircraft with the Hekla 2000 eruption plume in the lower stratosphere (Rose et al., 2006). Observations showed $\mathrm{OH}$ and $\mathrm{HO}_{2}$ were elevated at up to 0.5 and $15 \mathrm{pptv}$ above background in 33-34 h aged volcanic cloud during night. These measurements have eluded any explanation given the lack of photochemistry, a cooled plume, and anticipated fast $\mathrm{HO}_{x}$ destruction by reaction with volcanic $\mathrm{SO}_{2}$ and halogens (both in excess abundances). In general, the reported elevated abundances of $\mathrm{HO}_{x y}$ in volcanic plumes compared to the background atmosphere are surprising because low-temperature volcanic plume chemistry is expected to deplete $\mathrm{HO}_{x y}$ (Galeazzo et al., 2018). Volcanic $\mathrm{HO}_{x y}$ may originate from high-temperature chemistry of the near-source plume.

Elevated concentrations of $\mathrm{NO}, \mathrm{NO}_{2}$, and $\mathrm{HNO}_{3}$ have been measured in several volcanic plumes in the troposphere in addition to the $\mathrm{HO}_{2} \mathrm{NO}_{2}$ observed in the Mt Erebus plume: a review is given by Martin et al. (2012) and references therein, reporting a typical molar ratio for $\mathrm{NO}_{y} / \mathrm{H}_{2} \mathrm{O}$ of $10^{-5}$. Whilst filter pack sampling identified $\mathrm{HNO}_{3}$ in crater-rim plumes from several volcanoes (e.g., Mather et al., 2004a), on other occasions there was no evidence for $\mathrm{HNO}_{3}$, even at the same volcano (e.g., Martin et al., 2010). This may point to variability in emissionsprocessing or reliability of measurement technique. Nevertheless, real-time aircraft-based measurements by Atmospheric Chemical Ionization Mass Spectrometer confirm volcanic $\mathrm{HNO}_{3}$ in plumes downwind from Mt Etna at $\mathrm{HNO}_{3} / \mathrm{SO}_{2}=0.02$ (Voigt et al., 2014), and in the Mt Erebus plume (Oppenheimer et al., 2010). Sources of volcanic $\mathrm{NO}_{x y}$ are uncertain. Martin et al. (2012) present a kinetic model of $\mathrm{CHON}$ chemistry that demonstrates high-temperature formation of thermal $\mathrm{NO}_{x}$ is too slow to occur in the near-source plume that rapidly disperses and cools over seconds-minutes. Volcanic lightning is a likely source of $\mathrm{NO}_{x}$ in clouds from explosive eruptions. It has also been hypothesized that $\mathrm{NO}_{x}$ may sometimes be formed by oxidation of ammonia, for example in the stratospheric cloud from the Hekla 2000 eruption (Rose et al., 2006).

The need to characterize high-temperature chemistry in the near-source plume is underlined by model studies of volcanic halogen transformations in the plume (Bobrowski et al., 2007; von Glasow, 2010; Roberts et al., 2014). Halogens are emitted as hydrogen halides $(\mathrm{HBr}$ and $\mathrm{HCl})$ from volcanoes but are transformed into reactive halogens ( $\mathrm{BrO}$ and $\mathrm{OClO})$ in the tropospheric plume via a multi-phase autocatalytic "bromine-explosion" chemistry occurring at low-temperatures. However, numerical models of the plume atmospheric halogen chemistry can only reproduce the observed magnitude and rate of formation of $\mathrm{BrO}$ if the volcanic emission is modified to include radicals believed to form at high-temperatures in the near-source plume (the so-called "effective source region"). Radicals such as $\mathrm{OH}$ (that react with $\mathrm{HBr}, \mathrm{HCl}$ to produce $\mathrm{Br}$, and $\mathrm{Cl}$ ) provide an initial source of reactive bromine to initiate the low-temperature bromine explosion cycles. Furthermore, high-temperature production of sulfateprecursor $\mathrm{SO}_{3}$ generates near-source (so-called "primary") sulfate aerosols that promote heterogeneous reactions that drive the bromine explosion chemistry. Observations of $\mathrm{BrO}$ (and occasionally $\mathrm{OClO}$ ) in tropospheric volcanic plumes globally (e.g., Bobrowski et al., 2007; Boichu et al., 2011; Hörmann et al., 2013; Donovan et al., 2014; Kern and Lyons, 2018) indicate pervasive emissions of volcanic halogens to the troposphere accompanied by both high- and low-temperature chemistry in volcanic plumes.

The high-temperature region of the plume also facilitates gasash interactions including adsorption of gases such as $\mathrm{SO}_{2}$ and $\mathrm{HCl}$ onto ash particles that may then fall-out (Delmelle et al., 2018 and references therein). High-temperature $\mathrm{SO}_{3}$ is a precursor to sulfate that can condense as the eruption column cools and could change ash properties (e.g., Hoshyaripour et al., 2015) and ashrelated atmospheric impacts e.g., regarding plume lightning or ice nuclei. Whilst such heterogeneous interactions are outside the scope of our study, quantifying the high-temperature oxidizing chemistry occurring in the gas-phase as volcanic gases mix with air is a fundamental first-step to characterising the nearsource plume composition and its possible influence on gasash interactions.

Thermodynamic models such as HSC have been applied to calculate the equilibrium compositions of mixtures of magmatic gases with air, and HSC output has been used in numerical model studies of the plume atmospheric chemistry and impacts (e.g., Gerlach, 2004; Martin et al., 2006, 2007, 2009, 2011; Aiuppa et al., 2007; Bobrowski et al., 2007, 2015; Roberts et al., 2009, 2014, 2018; von Glasow, 2010; Martin and Ilyinskaya, 2011; Hoshyaripour et al., 2012; Ilyinskaya et al., 2012; Surl et al., 2015; Jourdain et al., 2016). HSC is used to calculate the composition of the nearsource plume for temperatures above $600^{\circ} \mathrm{C}$ according to Gibbs free energy minimization. The emission is released at magmatic temperatures and as the magmatic gases entrain air, the mixture cools toward background temperature. The calculation assumes thermodynamic equilibrium composition is reached at a specified temperature and degree of mixing of air with magmatic gases (often expressed as a volumetric or molar ratio, VA:VM where VA is air volume and VM is magmatic gas volume). Plume composition is then assumed to be "quenched" with respect to high-temperature chemistry upon further mixing with air. Choice of the VA:VM "quenching-point" for the HSC calculation is rather uncertain and may vary with eruption/emission type. For studies of passively degassing volcanoes it was found that a high VA:VM = 40:60 (Bobrowski et al., 2007) yielded extremely high $\mathrm{SO}_{3}$ relative to $\mathrm{SO}_{2}$ (much greater than observed sulfate/ $\mathrm{SO}_{2}$ ratios, see Table 1), therefore more recent studies chose lower VA:VM $=10: 90$ or 5:95 (e.g., Roberts et al., 2014) as the point where high-temperature chemistry is quenched. Conceivably, large eruptions might sustain high-temperature conditions over longer periods allowing the chemistry to reach equilibrium conditions at higher VA:VM. Hoshyaripour et al. (2012) simulated the high-temperature chemistry in an eruption column by co-varying VA:VM from 0 to 1 with temperature decreasing 


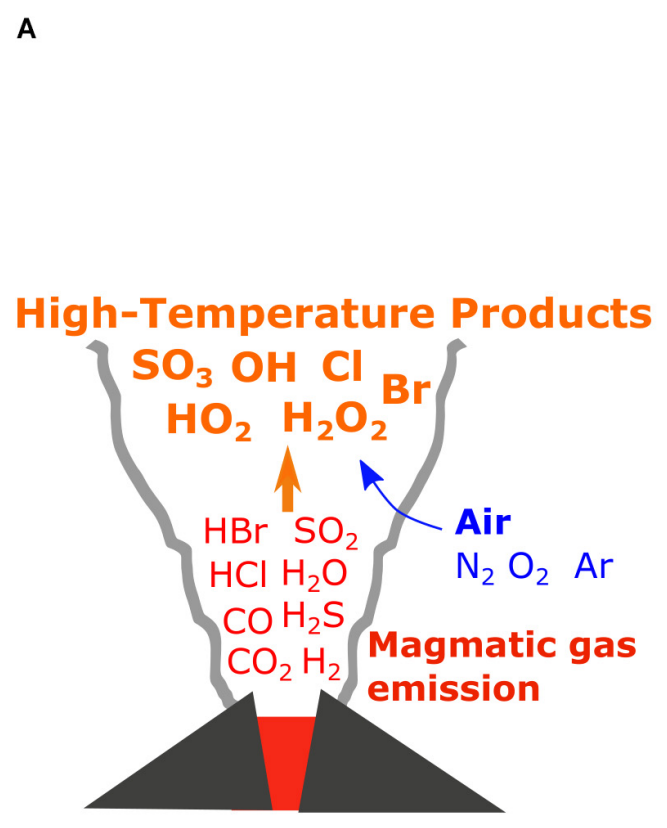

B

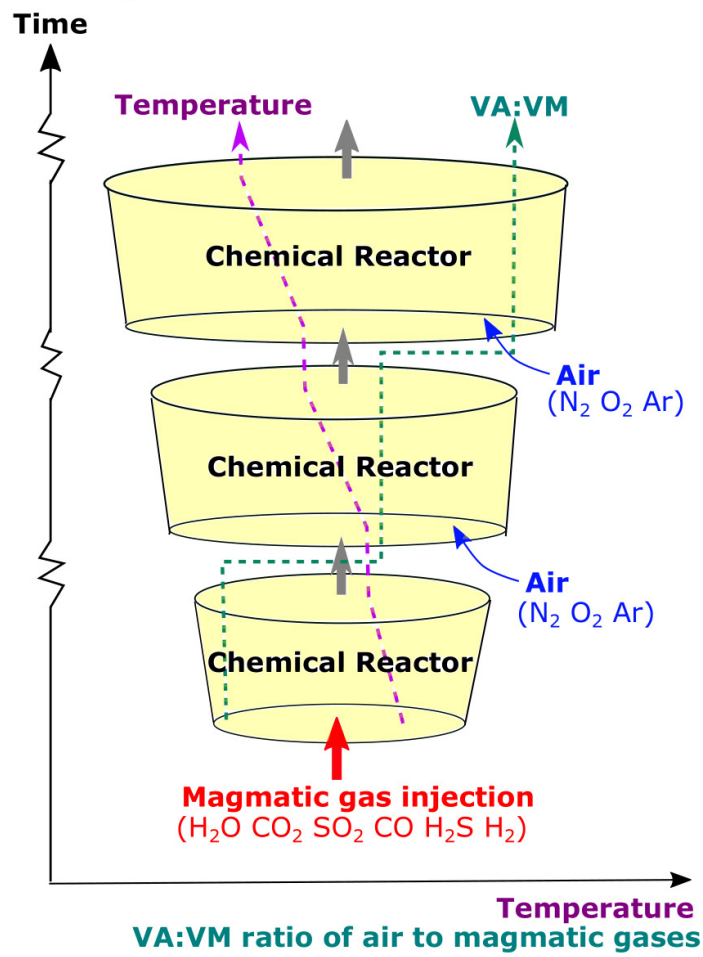

FIGURE 1 | Schematics of (A) high-temperature plume chemistry that generates radicals and oxidized products in the plume and (B) our chain-of-reactors approach to simulate the processes based on chemical kinetics under time-varying temperature (T) and proportion of mixing of air with magmatic gases (VA:VM).

from $1273 \mathrm{~K}$ to $873 \mathrm{~K}\left(1000^{\circ} \mathrm{C}\right.$ to $\left.600^{\circ} \mathrm{C}\right)$, predicting that the eruption column acts as a hot oxidizing reactor for $\mathrm{S}$ species.

In general, volcanic plume applications of thermodynamic equilibrium models such as HSC yield elevated abundances of $\mathrm{SO}_{x}$ (dominated by $\mathrm{SO}_{3}$ ), $\mathrm{HO}_{x}$ (dominated by $\mathrm{OH}$ ) and $\mathrm{NO}_{x}$ (dominated by $\mathrm{NO}$ ), and halogen radicals $\mathrm{Br}, \mathrm{Cl}$ (e.g., Martin et al., 2006). The relative abundances of these oxidized products increase with increasing VA:VM. The equilibrium models also predict near-complete oxidation of reduced gases emitted from volcanoes (e.g., $\mathrm{CO}, \mathrm{H}_{2} \mathrm{~S}$, and $\mathrm{H}_{2}$ ), yet these gas species are often detected at the crater-rim or in downwind (cooled) plumes (e.g., Aiuppa et al., 2005; Schumann et al., 2011; Moussallam et al., 2012; Roberts et al., 2012; de Moor et al., 2016). This suggests that some gas species may not always be under equilibrium control (Martin et al., 2009). Plume observations of reduced gases relative to major gases (e.g., $\mathrm{CO} / \mathrm{CO}_{2}, \mathrm{H}_{2} / \mathrm{H}_{2} \mathrm{O}$, and $\mathrm{H}_{2} \mathrm{~S} / \mathrm{SO}_{2}$ ) are used to infer emission properties such as temperature and oxidative state, but such inferences cannot hold true if there is substantial oxidation of the reduced gases following emission, as predicted by HSC. Here, a method is developed to evaluate how reaction rates control high-temperature chemistry of volcanic gases in air as a function of time-varying plume dynamics, Figure $\mathbf{1 .}$

Our model uses a chemical kinetics rather than thermodynamics approach, and requires time-resolved boundary conditions in both temperature and degree of mixing of magmatic gases with air (VA:VM), as well as the composition of the volcanic gases emitted as model input.
The temperature of the volcanic gas emission is uncertain. It is typically assumed to be identical to petrological magmatic estimates $\left(600-1200^{\circ} \mathrm{C}\right)$, although analysis of gas compositions measured at Kilauea, Hawaii (Oppenheimer et al., 2018) and Mt Etna, Italy (Aiuppa et al., 2011) show that gases may cool prior to emission into the atmosphere. Introduction of surface waters may also cool the gas emission. Physical properties of the plume are poorly constrained for the few seconds following release from the eruptive vent (or other emission sources e.g., lava lake or dome), as there are few direct measurements or dedicated model studies. A study of gas-puffing dynamics at passively degassing volcano Masaya yielded estimates of mean dilutions of 0.09 and 0.24 between emission and detection by thermal radiometer about $5-10 \mathrm{~m}$ above the vent, for gas puffs with mean velocities 2.5 and $4.3 \mathrm{~m} / \mathrm{s}$ (Branan et al., 2008).

One way to estimate temperature and VA:VM in the nearsource plume can be through dynamical model simulations of plume rise (e.g., Mastin, 2007; Aubry et al., 2017). This study relies on one such eruptive case to supply physical boundary conditions: the PlumeRise model applied to the 2010 Eyjafjallajökull eruption plume (Woodhouse et al., 2013), for which observations of volcanic gases including $\mathrm{CO} / \mathrm{SO}_{2}$ have also been reported both close to the source and far downwind (Allard et al., 2011; Schumann et al., 2011). This Eyjafjallajökull case forms the basis for an exploratory investigation into the chemical kinetics of gas-phase reactions occurring at high-temperatures in volcanic plumes. 


\section{MATERIALS AND METHODS}

Our approach to simulate high-temperature chemical reactions in the near-source plume includes three components: (i) the chemical kinetics model (chain-of-reactors), (ii) physical boundary conditions applied to the model, and (iii) the volcanic gas emissions injection as model input.

\section{Chemical Kinetic Model (Chain-of-Reactors)}

Chemkin is a fortran-based tool for incorporating complex chemical kinetics into model simulations of fluid dynamics (Kee et al., 2000 and related references from Reaction Design). Gas species and (reversible) reactions are first declared, as well as initial conditions (such as initial gas concentrations, temperature, pressure), and then the reactions are simulated in a plug-flow reactor (PFR) to evaluate temporal changes in gas composition.

Rates of progressions of reactions are quantified as the difference between the rate of the forward and reverse reactions, for example $\mathrm{E} 1$ for the reversible reaction $\mathrm{A}+\mathrm{B}=\mathrm{C}+\mathrm{D}$ (where gases $\mathrm{A}, \mathrm{B}, \mathrm{C}$, and $\mathrm{D}$ may also be involved in other reactions, each with its corresponding differential equation).

$$
\text { E1 } d[C] / d t=k_{f} \times[A] \times[B]-k_{r} \times[C] \times[D]
$$

The rate constants for forward reactions, $\mathrm{k}_{f}$, are described in the form, E2, where $R$ is the gas constant and $\mathrm{T}$ the gas temperature. The pre-exponential factor, $A$, the temperature exponent, $\beta$, and activation energy $\mathrm{E}$, are specified in the mechanism file (see Glarborg and Marshall, 2013).

$$
\text { E2 } \mathrm{k}_{\mathrm{f}}=\mathrm{A} \times \mathrm{T}^{\beta} \times \exp [-\mathrm{E} /(\mathrm{R} \times \mathrm{T})]
$$

The reverse reaction rate constant, $\mathrm{k}_{r}$, is given by $\mathrm{E} 3$ where $\mathrm{K}$ is the equilibrium constant that is determined by thermodynamic properties (molar enthalpies and entropies as a function of temperature); these properties are specified in the thermodynamic data file (see Glarborg and Marshall, 2013).

$$
\text { E3 } \mathrm{k}_{\mathrm{r}}=\mathrm{k}_{\mathrm{f}} / \mathrm{K}
$$

The Chemkin model also accounts for third-body, unimolecular, chemically activated reactions, and pressuredependencies of reaction rates. The resulting system of ordinary differential equations and initial conditions is solved by Chemkin to quantitatively predict how the gas composition in the chemical reactor evolves as a function of time according to the kinetics-based reaction scheme and the thermodynamic conditions.

The reaction mechanism applied within ChemKin is userspecified. There are very few studies at high-temperature dealing with sulfur species oxidation and their interactions with carbon, nitrogen oxides, or halogens. Here, the mechanism proposed by Glarborg and Marshall (2013) was selected for its good performance in comparison to laboratory shock-tube experiments, as recently highlighted by Mathieu et al. (2017). It includes 38 species involved in 161 reversible reactions. This reaction mechanism, and corresponding thermodynamic properties, relies on earlier works on sulfur chemistry and was updated to model the oxidation of carbonyl sulfide (OCS). A full list of gas species and chemical reactions is given in Supplementary Tables S1, S2. This version does not include halogens or $\mathrm{NO}_{x}$ chemistry. The interactions between sulfur, carbon, halogens, and nitrogen oxides are beyond the scope of this work, but will need to be addressed in future. Also, all the species considered were in the gas-phase; heterogeneous reactions or photochemical reactions were not included. This is a clear limitation of the present study which should be seen as a preliminary step needed to account for time evolution of chemicals in a near-source plume. Whilst the chemical scheme is one of the most complete regarding sulfur compounds, there exist some uncertainties in the high-temperature reaction kinetics, in particular related to $\mathrm{H}_{2} \mathrm{~S}$ (Mathieu et al., 2017). A single PFR simulates the high-temperature chemistry for given starting conditions in gas composition and temperature. A timevarying temperature can be introduced by applying a temperature gradient in the PFR and imposing an initial velocity of the reactor gases. However, air cannot be added as a function of time into a single reactor, i.e., the proportion of air to magmatic gases in the simulation is held constant according to the initial composition.

Therefore, a chain-of-reactors approach was developed using the Chemkin Pro software to simulate the chemical evolution of a near-source plume that simultaneously cools (decreasing $\mathrm{T}$ ) and entrains air (increasing VA:VM) as it dilutes, Figure $\mathbf{1 .}$ Thirty PFRs were placed in a chain. A continuous decreasing trend in plume temperature was imposed across the chain by defining the start and end temperatures for each PFR according to our chosen boundary conditions (details in the next section). The starting composition for each reactor was defined by taking the output from the preceding one and diluting it with air $\left(78 \% \mathrm{~N}_{2}, 21 \% \mathrm{O}_{2}, 1 \% \mathrm{Ar}\right)$ according to time-varying VA:VM boundary conditions. The pressure decrease was also considered even if it was not found to be significant. This alternate simulation of the plume chemistry (within reactor boxes) and mixing-dilution steps (between reactor boxes) is similar to the approach used in kinetics-based modeling of the low-temperature atmospheric chemistry of volcanic plumes e.g., PlumeChem (Roberts et al., 2009).

\section{Boundary Conditions to the Chain-of-Reactors Provided by PlumeRise Model}

The chain-of-reactors model requires time-resolved boundary conditions for plume temperature and VA:VM as the emitted volcanic gases rapidly mix with air. Here, output from the $1 \mathrm{D}$ PlumeRise model is used. PlumeRise describes the ascent of a turbulent buoyant plume composed of solid pyroclasts, magmatic gases, and air and includes the effects of cross-wind on turbulent entrainment of air into the plume. The PlumeRise dynamics model approximates volcanic gases as entirely $\mathrm{H}_{2} \mathrm{O}$ (a more complex emission composition provides input to the chain-ofreactors model, see Section "Magmatic Gas Emissions" below).

Output from the PlumeRise model includes the plume temperature ( $\mathrm{T}$, in $\mathrm{K}$ ), the total mass flux ( $\mathrm{Q}$ in $\mathrm{kg} / \mathrm{s})$, the gas 
mass fraction $(\mathrm{n})$, the vertical velocity, $U(\mathrm{~m} / \mathrm{s})$, the mass fraction of water (liquid+gas) in the plume $(\varphi)$, specific humidity $(C)$, and altitude ( $\mathrm{z}$ in $\mathrm{m}$ ), each provided at a resolution $(\mathrm{dz})$ of a few meters. These variables can be used to derive temperature and VA:VM as a function of time. The time, in seconds is given by E4, and integrating $\mathrm{dt}$.

$$
\mathrm{E} 4 \mathrm{dt}=\mathrm{dz} / \mathrm{U}
$$

The plume total mass (gases and solids), $\mathrm{M}$ in $\mathrm{kg}$, in the discrete volume at each time-step is given by E5.

$$
\text { E5 } \mathrm{M}=\mathrm{dz} \times \mathrm{Q} / \mathrm{U}
$$

The mass of all gases (volcanic $\mathrm{H}_{2} \mathrm{O}$ and air) in the plume, $\mathrm{M}_{(\mathrm{g})}$ is the product of $\mathrm{M}$ and the gas mass fraction, $\mathrm{n}, \mathrm{E} 6$.

$$
\text { E6 } \mathrm{M}_{(\mathrm{g})}=\mathrm{n} \times \mathrm{M}
$$

Under high temperature plume conditions, all $\mathrm{H}_{2} \mathrm{O}$ in the plume is in gaseous form, whose mass $\mathrm{M}_{(\mathrm{w})}$ is the product of $\mathrm{M}$ and $\varphi$, E7.

$$
\text { E7 } \mathrm{M}_{(\mathrm{w})}=\mathrm{M} \times \varphi
$$

The mass of dry air in the plume, $M_{(d a)}$ is the difference between $\mathrm{M}_{(\mathrm{g})}$ and $\mathrm{M}_{(\mathrm{w})}$, E8. The mass of background water in the plume, $\mathrm{M}_{(\mathrm{bw})}$ is the product of $\mathrm{M}_{(\mathrm{da})}$ with the specific humidity, $\mathrm{C}$, E9. The mass of volcanic gases (here: entirely as $\left.\mathrm{H}_{2} \mathrm{O}\right), \mathrm{M}_{(\mathrm{vg})}$, is the difference between $\mathrm{M}_{(\mathrm{w})}$ and $\mathrm{M}_{(\mathrm{bw})}$, E10.

$$
\begin{array}{r}
\text { E8 } \quad M_{(\mathrm{da})}=M_{(\mathrm{g})}-M_{(\mathrm{w})} \\
\text { E9 } \quad M_{(\mathrm{bw})}=M_{(\mathrm{da})} \times C \\
\text { E10 } \quad M_{(\mathrm{vg})}=M_{(\mathrm{w})}-M_{(\mathrm{bw})}
\end{array}
$$

The masses $\mathrm{M}_{(\mathrm{vg})}, \mathrm{M}_{(\mathrm{da})}$, and $\mathrm{M}_{(\mathrm{bw})}$ in $\mathrm{kg}$ are converted into moles of volcanic gases, dry air, and background water, $\mathrm{m}_{(\mathrm{vg})}$, $\mathrm{m}_{(\mathrm{da})}, \mathrm{m}_{(\mathrm{bw})}$, by dividing by their respective molecular weights $\left(18 \times 10^{-3}\right.$ for $\mathrm{H}_{2} \mathrm{O}$ and $29 \times 10^{-3}$ for dry air containing $\mathrm{N}_{2}$, $\mathrm{O}_{2}$, and $\mathrm{Ar}$, expressed as $\left.\mathrm{kg} / \mathrm{mol}\right), \mathrm{E} 11,12,13$. The total moles of entrained wet air, $\mathrm{m}_{(\text {air })}$, is calculated by the sum of $\mathrm{m}_{(\mathrm{da})}$ and $\mathrm{m}_{(\mathrm{bw})}, \mathrm{E} 14$.

$$
\begin{aligned}
\mathrm{E} 11 & \mathrm{~m}_{(\mathrm{da})}=\mathrm{M}_{(\mathrm{da})} /\left(29 \times 10^{-3}\right) \\
\mathrm{E} 12 & \mathrm{~m}_{(\mathrm{vg})}=\mathrm{M}_{(\mathrm{vg})} /\left(18 \times 10^{-3}\right) \\
\mathrm{E} 13 & \mathrm{~m}_{(\mathrm{bw})}=\mathrm{M}_{(\mathrm{bw})} /\left(18 \times 10^{-3}\right) \\
& \mathrm{E} 14 \mathrm{~m}_{(\text {air })}=\mathrm{m}_{(\mathrm{da})}+\mathrm{m}_{(\mathrm{bw})}
\end{aligned}
$$

Finally, the ratio VA:VM is the moles of wet air divided by moles of volcanic gases, E15.

$$
\mathrm{E} 15 \quad \mathrm{VA}: \mathrm{VM}=\mathrm{m}_{(\text {air })} / \mathrm{m}_{(\mathrm{vg})}
$$

The calculation yields VA:VM as a function of $\mathrm{dz}$ or time when performed for each row of output from the 1D plume dynamics model. Assumptions that water exists purely in the gas phase and that water content is dominated by the volcanic emission are valid for the hot and concentrated plume region investigated in this study. The resulting trend in temperature with
VA:VM is consistent with simple specific-heat calculations for the magmatic-air-ash mixture. Plume temperature and VA:VM depend strongly on the $\mathrm{T}, \mathrm{n}, \mathrm{U}$ starting conditions used for the PlumeRise model.

Several PlumeRise 1D model results showing decreasing temperature and increasing VA:VM with time or distance from the source are shown in Supplementary Figure S1, for the Eyjafjallajökull eruption April 14-17, 2010. These are based on the model runs of Woodhouse et al. (2013) that used meteorological data from local balloon soundings ${ }^{1}$. The model input parameters are only partially constrained, but Woodhouse et al. (2013) found good predictive capability of the model to reproduce plume height for starting parameter ranges of temperature $T=600-1000 \mathrm{~K}$, vertical velocity $\mathrm{U}=50-100 \mathrm{~m} / \mathrm{s}$, gas mass fraction $n=0.030-0.086$ (Woodhouse et al., 2013; Supplementary Table S3). Notably, the model runs are highly diverse in their starting temperatures and predicted VA:VM. The starting temperatures are all substantially lower than petrological estimates of the magmatic temperature, (Keiding and Sigmarsson, 2012) who reported $1443 \mathrm{~K}\left(1170 \pm 25^{\circ} \mathrm{C}\right)$ for the early flank eruption, and $1273-1333 \mathrm{~K}\left(1000-1060^{\circ} \mathrm{C}\right)$ for benmoritic products related to the main summit eruption that are pertinent to this study. Reasons for this are unclear but could be due to decoupling of magmatic and gas temperatures or a cooling effect of incorporated water. The Introduction Section "High-Temperature Products in Volcanic Plumes: Observations and Modeling" highlighted considerable uncertainty in the physical conditions (temperature, VA:VM) of the near-source plume.

In this exploratory study we use output from the PlumeRise simulation with starting temperature at $1000 \mathrm{~K}$ as example boundary conditions in time-varying $\mathrm{T}$ and VA:VM as a basis for chemical kinetics modeling of the hot plume chemistry. This chosen PlumeRise dynamics scenario from Woodhouse et al. (2013) combined with magmatic gas emissions based on Allard et al. (2011; Table 2) yields an $\mathrm{SO}_{2}$ flux of $5.5 \mathrm{kt} / \mathrm{hr} \mathrm{SO}_{2}$, that is consistent with the range of $\mathrm{SO}_{2}$ fluxes derived from satellite observations during the Eyjafjallajökull eruption (Boichu et al., 2013).

\section{Magmatic Gas Emissions}

A volcanic gas emission composition is input to the chain-ofreactors model, based on reported observations. It should be emphasized that available observations are an imperfect basis for the initialization of model of high-temperature chemistry in the near-source plume. First, no individual measurement technique can observe all gases in a volcanic plume. Available observations may not fully characterize all magmatic gases in the emission, nor any temporal evolution in their release as a function of volcanic activity. Second, observations of the cooled or partially cooled plume necessarily already incorporate any high-temperature modification of the emissions. Our use of such observations inherently assumes that preceding plume chemistry has only slightly modified the volcanic gas emission. This is indeed the prevalent assumption behind near-source monitoring

\footnotetext{
${ }^{1}$ http://weather.uwyo.edu/upperair/sounding.html
} 
TABLE 2 | Magmatic gas compositions (mole fraction) used as input to the chain-of-reactors model simulations.

\begin{tabular}{lcc}
\hline Volcanic gas & Eyja CO & Eyja CO-H $\mathbf{2} \mathbf{S}-\mathbf{H}_{\mathbf{2}}$ \\
\hline $\mathrm{H}_{2} \mathrm{O}$ & 0.916 & 0.916 \\
$\mathrm{CO}_{2}$ & 0.08 & 0.08 \\
$\mathrm{SO}_{2}$ & 0.002 & 0.002 \\
$\mathrm{H}_{2} \mathrm{~S}$ & - & 0.00000145 \\
$\mathrm{HCl}$ & $(0.0013)$ & $\times(0.0013)$ \\
$\mathrm{HF}$ & - & - \\
$\mathrm{HBr}$ & - & - \\
$\mathrm{H}$ & - & 0.00237 \\
$\mathrm{CO}$ & 0.00035 & 0.00035 \\
\hline
\end{tabular}

$X$ means that the gas was replaced by Ar. The emission composition is based on field-observations of Eyjafjallajökull's summit 2010 eruption (Allard et al., 2011). A second Eyjafjallajökull emission scenario includes theoretical estimates of $\mathrm{H}_{2}$ and $\mathrm{H}_{2} \mathrm{~S}$. A sensitivity study also investigated emissions excluding $\mathrm{CO}$ or $\mathrm{SO}_{2}$.

of volcanic gas emissions (with the exception of volcanic $\mathrm{BrO}$, e.g., Guttmann et al., 2018). Unfortunately, sources such as lava bodies are typically hazardous and inaccessible, therefore few direct measurements are available of the gas emission prior to any mixing with air.

In this study the composition of the Eyjafjallajökull magmatic gas emission is based on observations of $\mathrm{H}_{2} \mathrm{O}-\mathrm{CO}_{2}-\mathrm{SO}_{2}-\mathrm{CO}$ $(\mathrm{HCl})$ in the young plume of the summit eruption reported by Allard et al. (2011) who performed FTIR spectroscopy of volcanic gases in early May 2010, using hot rocks as an IR source. Note that the volcanic emission of $\mathrm{HCl}$ was replaced by $\mathrm{Ar}$ in our modeling that does include halogens. The emission scenarios for the model studies are summarized in Table 2.

A first simulation emissions scenario (Eyja CO) is based entirely on observations of Allard et al. (2011). This emission contains $\mathrm{CO}$ but no other reduced gases such as $\mathrm{H}_{2}$ or $\mathrm{H}_{2} \mathrm{~S}$, which typically cannot be resolved in this experimental set up. HF was also not reported, being below detection limits. The measurements by Allard et al. (2011) yield a $\mathrm{CO} / \mathrm{SO}_{2}$ molar ratio of 0.175 and $\mathrm{CO} / \mathrm{CO}_{2}=0.0044$. To evaluate how the presence of $\mathrm{CO}$ and $\mathrm{SO}_{2}$ impact the high-temperature chemistry of the nearsource plume, sensitivity studies were undertaken that excluded $\mathrm{CO}$ and $\mathrm{SO}_{2}$ from the emission (Eyja no-CO no-SO2).

A further simulation (Eyja $\mathrm{CO}-\mathrm{H}_{2}-\mathrm{H}_{2} \mathrm{~S}$ ) was undertaken that included estimates for $\mathrm{H}_{2}$ and $\mathrm{H}_{2} \mathrm{~S}$ in the Eyjafjallajökull emission (based on thermodynamic equilibrium calculations) alongside $\mathrm{CO}$ and the other gases reported by Allard et al. (2011). It is assumed that the magmatic gases were in thermodynamic equilibrium and at magmatic temperature on emission. For the Eyjafjallajökull summit eruption a temperature of $1273 \mathrm{~K}$ is assumed (Keiding and Sigmarsson, 2012). The gases obey the equilibria $\mathrm{CO}+0.5 \mathrm{O}_{2}=\mathrm{CO}_{2}, \mathrm{H}_{2}+0.5 \mathrm{O}_{2}=\mathrm{H}_{2} \mathrm{O}, \mathrm{H}_{2} \mathrm{~S}$ $+1.5 \mathrm{O}_{2}=\mathrm{SO}_{2}+\mathrm{H}_{2} \mathrm{O}$ with corresponding thermodynamic equilibrium constants of $1.13 \times 10^{7}, 1.92 \times 10^{7}$, and $1.54 \times 10^{17}$ at $1273 \mathrm{~K}$ (constants obtained from HSC). For these conditions the $\mathrm{CO} / \mathrm{CO}_{2}$ molar ratio 0.0044 observed by Allard et al. (2011) corresponds to an oxygen fugacity of $4.0 \times 10^{-10}$ bar (i.e., $\mathrm{QFM}+1.6 \log$ units). The corresponding $\mathrm{H}_{2} \mathrm{O} / \mathrm{H}_{2}$ molar ratio is 387 and $\mathrm{SO}_{2} / \mathrm{H}_{2} \mathrm{~S}$ molar ratio is 1379 . Combining these theoretical molar ratios with the mole fraction composition for $\mathrm{H}_{2} \mathrm{O}$ and $\mathrm{SO}_{2}$ in Table 2 yields estimates for the mole fractions of $\mathrm{H}_{2}=0.0024$ and $\mathrm{H}_{2} \mathrm{~S}=1.45 \times 10^{-6}$ in the Eyjafjallajökull emission. Thus, it is predicted that the eruption emitted a similar quantity (by mole) of $\mathrm{H}_{2}$ compared to $\mathrm{SO}_{2}$, but only a trace emission of $\mathrm{H}_{2} \mathrm{~S}$.

Some volcanoes release a larger proportion of sulfur in reduced forms. To investigate the potential impact of $\mathrm{H}_{2} \mathrm{~S}$ on the high-temperature chemistry of near-source volcanic plumes, we undertook a sensitivity study using a composition based on measurements made at Mt Etna (passive degassing) whose emission composition is still relatively oxidized, but includes $\mathrm{H}_{2} \mathrm{~S}$ (Roberts et al., 2017 and references therein) and $\mathrm{H}_{2}$ (Aiuppa et al., 2011; Supplementary Table S4). We emphasize that our combination of Eyjafjallajökull plume dynamics with $\mathrm{Mt}$ Etna emission composition for this sensitivity study is not representative of plume chemistry for Mt Etna passive degassing conditions. Rather it reflects a possible scenario for an ash-rich explosion from Mt Etna, assuming emission composition similar to that observed during passive degassing, and plume dynamics similar to Eyjafjallajökull. The Mt Etna composition used as input to our kinetics-model study is identical to the input used for a thermodynamic model study by Martin et al. (2011) [where the $\mathrm{H}_{2}$ emission was calculated theoretically and is somewhat higher than that observed by Aiuppa et al. (2011)]. Notably, the $\mathrm{SO}_{2}$ content of the Mt Etna emission composition (0.029 mole fraction) is more than an order of magnitude higher than the $\mathrm{SO}_{2}$ content of Eyjafjallajökull emission (0.002 mole fraction). The $\mathrm{H}_{2} \mathrm{~S}$ content of the emission is also much higher for Mt Etna (also with a higher ratio to $\mathrm{SO}_{2}$ ), whilst the $\mathrm{H}_{2}, \mathrm{H}_{2} \mathrm{O}$, and $\mathrm{CO}_{2}$ mole fractions are similar (although ratios to $\mathrm{SO}_{2}, \mathrm{X} / \mathrm{SO}_{2}$, are lower). A sensitivity study was also performed without $\mathrm{H}_{2} \mathrm{~S}$ in the Etna emission (Etna no- $\mathrm{H}_{2} \mathrm{~S}$ ).

\section{Equilibrium Modeling: HSC Thermodynamic Model}

Our study compares output from the chemical kinetics model outlined above to an equilibrium model (HSC) that has been previously applied to investigate volcanic plume chemistry (e.g., Martin et al., 2006). HSC model version 7.1 was used to calculate equilibrium compositions of mixtures of air with magmatic gases under the same temperature and VA:VM boundary conditions as for the chain-of-reactors model. The input composition was determined by mixing air (composed of $78 \% \mathrm{~N}_{2}, 21 \% \mathrm{O}_{2}$ and $1 \%$ Ar) with the Eyjafjallajökull magmatic gas composition (Table 2) for each VA:VM, whilst temperature was specified according to the PlumeRise boundary conditions. Pure magmatic gases are usually assumed to have compositions at chemical equilibrium when they are released from the volcano (and there is good evidence for this to first order for major Cand S-bearing species, e.g., Oppenheimer et al., 2018); however, some repartitioning of Eyjafjallajökull gases may be expected for thermodynamic equilibrium calculations even at VA:VM $=0: 100$ because the reported gas emission composition is incomplete and the initial PlumeRise temperature is slightly lower than magmatic temperature (see section "Magmatic Gas Emissions"). 


\section{RESULTS}

\section{Model Diagnostics: Cooling and Mixing of Volcanic Gases With Air}

Physical parameters from the PlumeRise model (temperature T, $\mathrm{VA}: \mathrm{VM}$, distance from the source, and plume cross-sectional area) used as boundary conditions for the chain-of-reactors model vary as a function of time, Figures 2A,B. Temperature is varied smoothly across the chain-of-reactors and decreases from $1000 \mathrm{~K}$ to $890 \mathrm{~K}$ (over the $30 \mathrm{PFRs}$ ) whereas VA:VM increases stepwise from 0 to 5.3 due to air-entrainment between each reactor. This $\mathrm{T}$ and VA:VM scenario is not representative of all volcanoes. Smaller volcanic emissions would likely disperse faster, particularly if ash-poor. The presence of ash in Eyjafjallajökull plume maintains high temperatures at higher VA:VM than would occur in an ash-poor emission (that for example for VA:VM $>3$ would yield $T<500 \mathrm{~K}$ according to simple gasphase mixing). This result is not surprising given 1D plumerise models of explosive eruptions typically assume an emission containing volcanic gases at a few weight-percent, with the remainder as pyroclasts. We highlight that this "temperature buffering" effect of ash may significantly prolong the period in which volcanic gases undergo high-temperature chemistry as they mix with air.

As VA:VM increases, the abundance of air-dominated gases such as $\mathrm{O}_{2}$ increases step-wise toward an asymptote of $21 \%$ (pure air) whilst major magmatic gases such as $\mathrm{H}_{2} \mathrm{O}$ and $\mathrm{CO}_{2}$ decrease step-wise due to dilution, Figure 2C. Plume chemistry can additionally cause gas abundances to rise or fall within each reactor. Figure $2 \mathrm{C}$ shows that there is negligible or only small impact of plume chemistry on $\mathrm{O}_{2}, \mathrm{H}_{2} \mathrm{O}$, and $\mathrm{CO}_{2}$ whose abundances are largely controlled by air entrainment/dilution. Also shown in Figure 2C is the product of the $\mathrm{O}_{2}$ and $\mathrm{H}_{2} \mathrm{O}$ mole fractions that reaches a maximum at around $0.5 \mathrm{~s}$, of relevance to the high-temperature reactions discussed in Section "Discussion."

\section{High-Temperature Production of Oxidants and Radicals}

The chemical evolution of the Eyjafjallajökull near-source plume according to the high-temperature chain-of-reactors model is shown in Figure 3A (Eyja CO run) over a time-period of about $2.4 \mathrm{~s}$, during which VA:VM increases from 0 to 5.3, and temperature decreases from $1000 \mathrm{~K}$ to $890 \mathrm{~K}$. The slight declines in major gases $\mathrm{H}_{2} \mathrm{O}, \mathrm{CO}_{2}$, and $\mathrm{SO}_{2}$ mixing ratios show they are largely under the control of dilution whilst air is entrained, i.e., are largely conserved. The production of oxidant radicals such as $\mathrm{OH}, \mathrm{HO}_{2}$, and $\mathrm{H}_{2} \mathrm{O}_{2}$ increases rapidly with plume time evolution during the first $0.5 \mathrm{~s}$, after which their absolute mixing ratios decrease. Formation of $\mathrm{SO}_{3}$ follows a similar pattern. The volcanic gas $\mathrm{CO}$ decreases only slightly faster than the major gases, indicating that it is not substantially oxidized by the plume chemistry. The general pattern is similar for the Eyja $\mathrm{CO}-\mathrm{H}_{2}-\mathrm{H}_{2} \mathrm{~S}$ simulation, Figure 3B: a higher maximum abundance of oxidant radicals is reached (slightly earlier) and slightly more CO is oxidized,

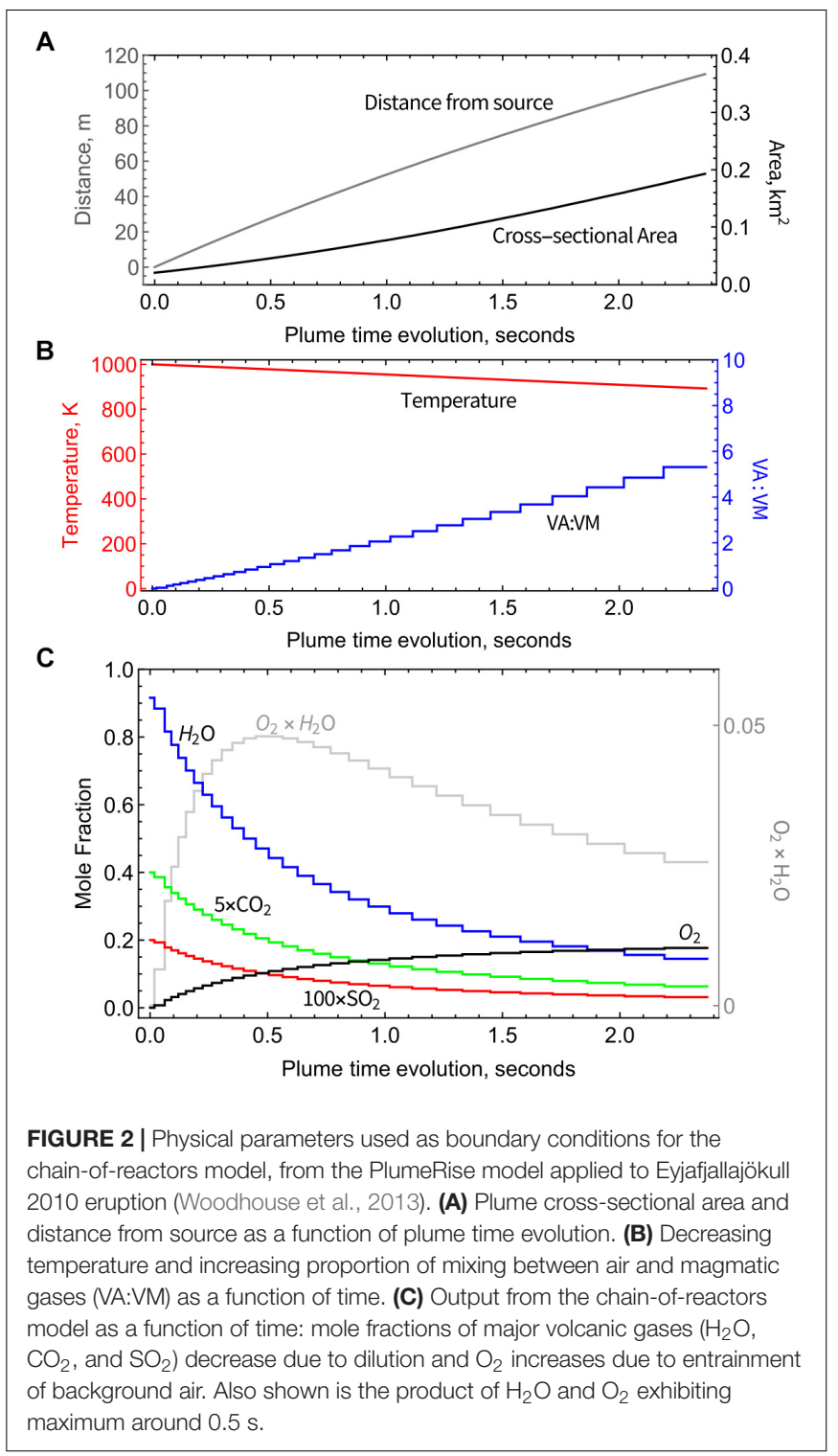

but still not completely depleted. In the Eyja CO- $\mathrm{H}_{2}-\mathrm{H}_{2} \mathrm{~S}$ simulation both volcanic gases $\mathrm{H}_{2}$ and $\mathrm{H}_{2} \mathrm{~S}$ become oxidized at around 0.5 s. To analyze the chemical kinetics model results in more detail and compare to field-observations and thermodynamic calculations, ratios are presented of the minor volcanic gases relative to the major (largely conserved) gases $\mathrm{SO}_{2}$, $\mathrm{CO}_{2}$, and $\mathrm{H}_{2} \mathrm{O}$.

\section{Oxidation of $\mathrm{CO}$ Is Kinetics Limited in the Near-Source Plume}

$\mathrm{CO}$ is only slightly oxidized by high-temperature chemistry, as shown by $\mathrm{CO} / \mathrm{SO}_{2}$ ratio, Figure $4 \mathrm{~A}$ (as well as $\mathrm{CO} / \mathrm{CO}_{2}$, Figure $4 \mathrm{~B}$ ). At the end of the simulations (VA: $\mathrm{VM}=5.3$ after $2.4 \mathrm{~s}), \mathrm{CO} / \mathrm{SO}_{2}$ has only declined by about $15 \%$ of the initial ratios for Eyja CO, and by $37 \%$ of the initial ratios for Eyja CO$\mathrm{H}_{2}-\mathrm{H}_{2} \mathrm{~S}$. In contrast, HSC thermodynamic calculations predict near-complete oxidation of $\mathrm{CO}$ as soon as air is mixed with the 

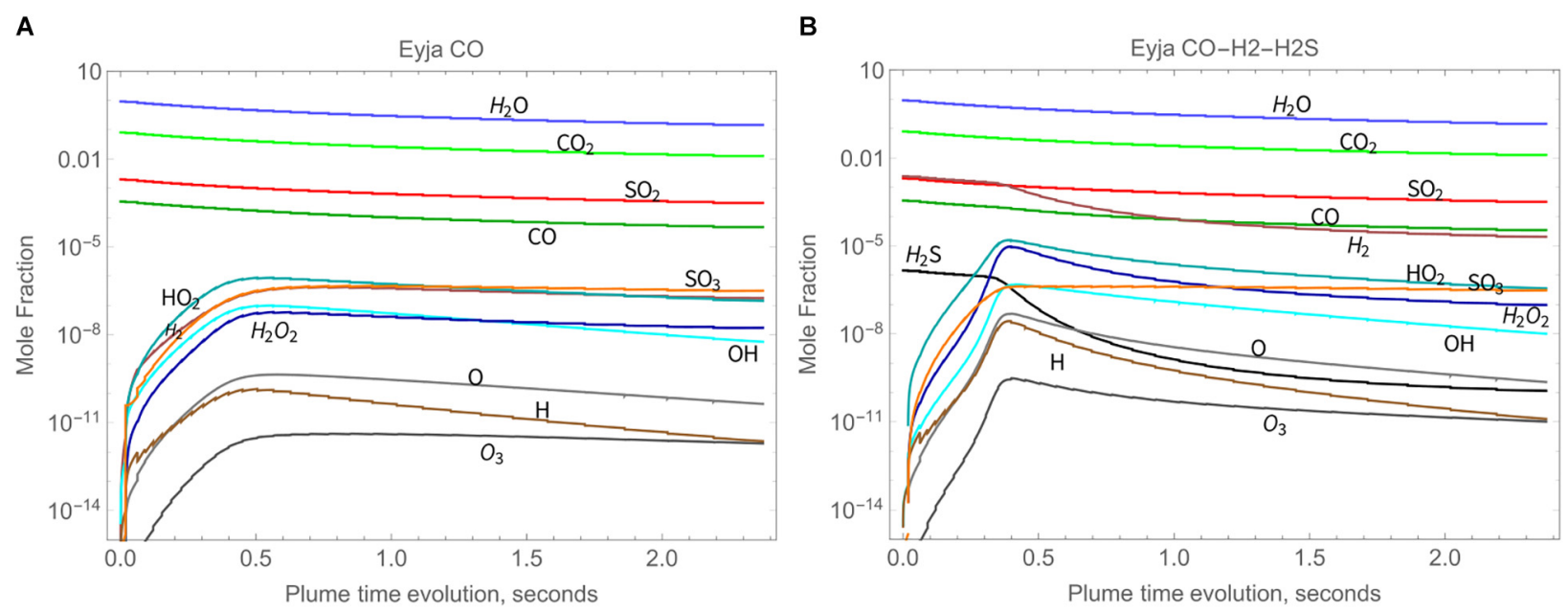

FIGURE 3 | High-temperature oxidant and radical production as a function of time in Eyjafjallajökull plume according to the chain-of-reactors model for two initial compositions, both of which include major volcanic gases $\mathrm{H}_{2} \mathrm{O}, \mathrm{CO}_{2}$, and $\mathrm{SO}_{2}$, as well as additional emitted gases as named: (A) Eyja CO and (B) Eyja CO- $\mathrm{H}_{2}-\mathrm{H}_{2} \mathrm{~S}$.

volcanic gases (VA:VM > 0), Figure 4. The kinetics model results are thus far more consistent with the presence of $\mathrm{CO}$ observed in the young Eyjafjallajökull plume by FTIR (Allard et al., 2011) and indeed in other volcanic gas emissions from more reduced magmas, e.g., at Mt Erebus (Oppenheimer and Kyle, 2008).

Additional observations of volcanic CO in the Eyjafjallajökull plume are reported by Schumann et al. (2011) who made instrumented aircraft measurements of the aged (10-100 h) plume over Europe during mid-April to mid-May. Both CO and $\mathrm{SO}_{2}$ were observed above background levels. The molar ratio of excess $\mathrm{CO}$ and excess $\mathrm{SO}_{2}$ (as averages) in transects of the aged plume is around $\sim 1$, i.e., somewhat higher than the ratio reported by Allard et al. (2011) in the young plume. Reasons for this discrepancy are not clear. It is unlikely that $\mathrm{CO}$ was formed in the plume in an oxidizing atmosphere. Plume structure in the aircraft measurements as reported by Schumann et al. (2011) is smoother for $\mathrm{SO}_{2}$ compared to CO. This may in part be due to the vastly different response times of the aircraft-based instruments for $\mathrm{SO}_{2}$ (T95 response time to reach $95 \%$ signal is $80 \mathrm{~s}$ ) and $\mathrm{CO}$ (response time $<2 \mathrm{~s}$ ), which might cause a high bias in the derived $\mathrm{CO} / \mathrm{SO}_{2}$. There is some scatter in the $\mathrm{CO}$ and $\mathrm{SO}_{2}$ measurements as well as variability in background $\mathrm{CO}$. In addition, $\mathrm{SO}_{2}$ could undergo atmospheric oxidation processes, resulting in an increase in the $\mathrm{CO} / \mathrm{SO}_{2}$ ratio in the downwind plume. Unusually, at Erebus volcano a rapid loss of $\mathrm{SO}_{2}$ has been identified in the very young plume possibly aided by cloud processing (Oppenheimer et al., 2010). However, oxidation of $\mathrm{SO}_{2}$ in volcanic plumes is typically slow (e.g., Galeazzo et al., 2018). The measurements of $\mathrm{CO} / \mathrm{SO}_{2}$ in the downwind Eyjafjallajökull plume do not show any clear dependency on plume age. In any case, the aircraft measurements of Schumann et al. (2011) detected volcanic plume $\mathrm{CO}$ alongside $\mathrm{SO}_{2}$, confirming that $\mathrm{CO}$ was emitted during the 2010 Eyjafjallajökull eruption and that CO was not substantially oxidized by high-temperature nearsource chemistry as is commonly predicted by thermodynamic modeling. Oxidation of CO was evidently kinetics-limited in the transient near-source plume. A summary of the model and observed $\mathrm{CO} / \mathrm{SO}_{2}$ is given in Table 3 .

The Eyja $\mathrm{CO}-\mathrm{H}_{2}-\mathrm{H}_{2} \mathrm{~S}$ simulation that includes theoretical estimates for volcanic emission of $\mathrm{H}_{2}$ and $\mathrm{H}_{2} \mathrm{~S}$ predicts nearcomplete oxidation of both gases, Figure $4 \mathrm{~B}$, as well as partial oxidation of CO. This is due to an oxidant enhancing feedback mechanism (see section "Discussion"). No specific observations of $\mathrm{H}_{2}$ or $\mathrm{H}_{2} \mathrm{~S}$ are available for comparison in the Eyjafjallajökull near-source or far downwind plume. However, observations of $\mathrm{H}_{2} \mathrm{~S}$ in plumes from both passively degassing volcanoes (e.g., Roberts et al., 2017) and explosive eruption plumes (e.g., de Moor et al., 2016) indicate that $\mathrm{H}_{2} \mathrm{~S}$ is (largely) conserved, as for $\mathrm{CO}$. Measurements of $\mathrm{H}_{2}$ have been reported in plumes from some passively degassing volcanoes (e.g., Aiuppa et al., 2011; Moussallam et al., 2012). In general, observations of reduced gases in volcanic plumes (specifically $\mathrm{CO} / \mathrm{CO}_{2}, \mathrm{H}_{2} \mathrm{O} / \mathrm{H}_{2}$, and $\mathrm{SO}_{2} / \mathrm{H}_{2} \mathrm{~S}$ gas ratios) may be used to infer magmatic properties at emission such as oxygen fugacity (see section "Magmatic Gas Emissions"), on the condition that modification of the emitted composition by near-source plume chemistry is either negligible or well-constrained by plume chemistry models. Here the small decrease in $\mathrm{CO} / \mathrm{CO}_{2}$ predicted by the kinetics model (Eyja $\mathrm{CO}$ ) is equivalent to a difference in oxygen fugacity of $1.5 \times 10^{-10}$ bars or about $0.14 \log$ unit QFM. We highlight two important areas of model uncertainty regarding the near-source oxidation of reduced gases. First, the reactions are temperature-dependent yet the temperature of the volcanic gas emission as well as subsequent plume physical evolution are both rather poorly known. Second, the kinetics of certain reactions, particularly for $\mathrm{H}_{2} \mathrm{~S}$ are poorly constrained by laboratory experiments. Thus, the presence of $\mathrm{H}_{2}$ and $\mathrm{H}_{2} \mathrm{~S}$ observed in certain volcanic plumes may suggest either a lower emission temperature or faster cooling rate than the Eyjafjallajökull case presented here, or may reflect uncertainties in the model chemical schemes. 


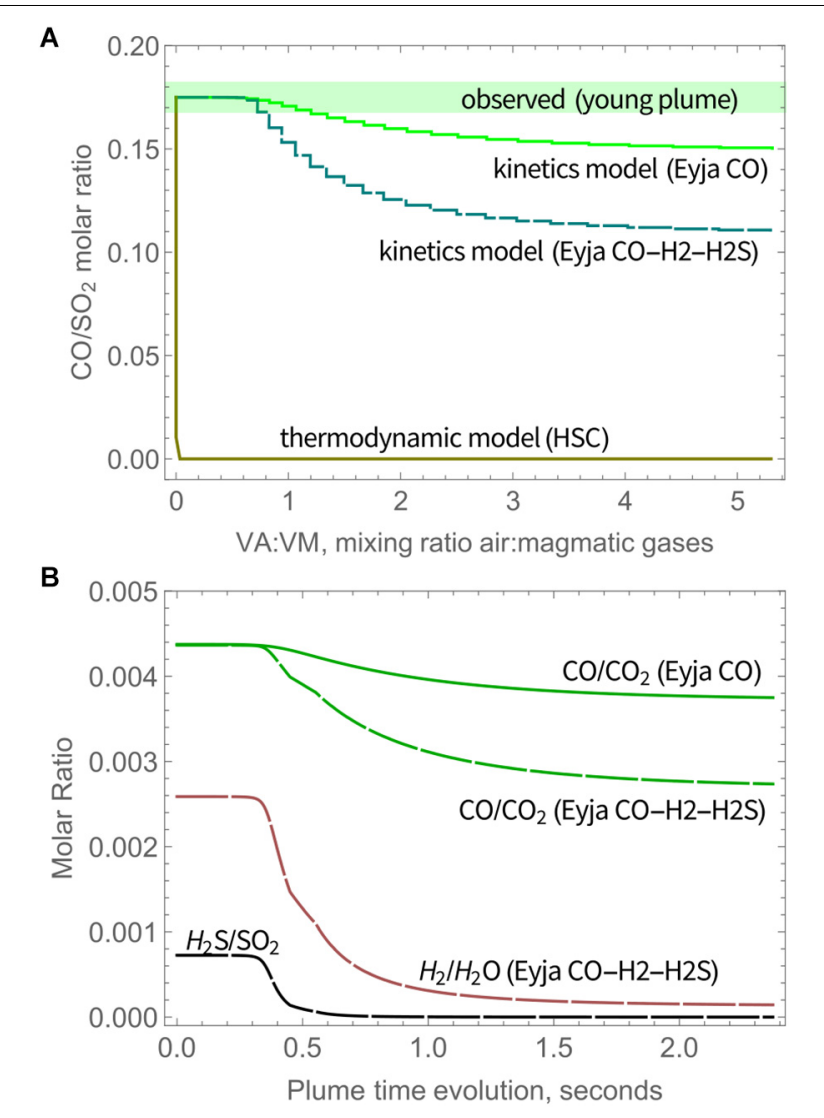

FIGURE 4 | (A) Molar ratio of $\mathrm{CO} / \mathrm{SO}_{2}$ in Eyjafjallajökull plume as a function of time according to the chain-of-reactors model for Eyja $\mathrm{CO}$ and Eyja $\mathrm{CO}-\mathrm{H}_{2}-\mathrm{H}_{2} \mathrm{~S}$ simulations, and the HSC thermodynamic model, compared to $\mathrm{CO} / \mathrm{SO}_{2}$ observed in the young plume by Allard et al. (2011), see also Table 3. Solid lines: Eyja CO simulation, Dashed lines: Eyja CO- $\mathrm{H}_{2} \mathrm{~S}-\mathrm{H}_{2}$ simulation. (B) Molar ratio of $\mathrm{CO} / \mathrm{CO}_{2}$ (Eyja $\mathrm{CO}$ and Eyja $\mathrm{CO}-\mathrm{H}_{2}-\mathrm{H}_{2} \mathrm{~S}$ simulations) as well as $\mathrm{H}_{2} \mathrm{~S} / \mathrm{SO}_{2}$ and $\mathrm{H}_{2} / \mathrm{H}_{2} \mathrm{O}$ (Eyja CO- $\mathrm{H}_{2}-\mathrm{H}_{2} \mathrm{~S}$ simulation only) as a function of time according to the chain-of-reactors model. Solid lines: Eyja $\mathrm{CO}$ simulation, Dashed lines: Eyja CO- $\mathrm{H}_{2} \mathrm{~S}-\mathrm{H}_{2}$ simulation.

\section{High-Temperature Production of $\mathrm{SO}_{3}$ as a Sulfate Aerosol Precursor}

$\mathrm{SO}_{3}$ abundance in magmatic gas is negligible but is predicted to form through high-temperature plume chemistry. $\mathrm{SO}_{3}$ is a precursor to sulfate aerosol (as is well-known e.g., from studies of power station emissions). Upon further plume cooling, volcanic $\mathrm{SO}_{3}$ will react readily with $\mathrm{H}_{2} \mathrm{O}_{(\mathrm{g})}$ to form $\mathrm{H}_{2} \mathrm{SO}_{4}(\mathrm{~g})$ that is highly hygroscopic and will form sulfate particles. The widespread observation of near-source volcanic sulfate (see section "Introduction," Table 1), motivates our model investigation of high-temperature $\mathrm{SO}_{3}$ as a possible sulfate source. The $\mathrm{SO}_{3}$ abundance increases rapidly at around $0.5 \mathrm{~s}$, Figure 5A. The $\mathrm{SO}_{3} / \mathrm{SO}_{2}$ molar ratio increases throughout the model simulations, indicating a continual production of $\mathrm{SO}_{3}$ that is similar for Eyja $\mathrm{CO}$ and Eyja $\mathrm{CO}-\mathrm{H}_{2}-\mathrm{H}_{2} \mathrm{~S}$. By the end of the simulations $(2.4 \mathrm{~s}, \mathrm{VA}: \mathrm{VM}=5.3, T=890 \mathrm{~K})$, the $\mathrm{SO}_{3} / \mathrm{SO}_{2}$ molar ratio reaches $10^{-3}$. The fact that $\mathrm{SO}_{3} / \mathrm{SO}_{2}$ ratio is still increasing at the end of the model simulation indicates that additional
TABLE 3 | Molar $\mathrm{CO} / \mathrm{SO}_{2}$ ratio observed in Eyjafjallajokull eruption plume compared to model predictions.

Measurement/mode $\mathrm{CO} / \mathrm{SO}_{2}$ molar ratio

FTIR observations of the young plume on May 0.175 08, 2010 (Allard et al., 2011)

Aircraft measurements of the downwind plume on April 22, 2010 - May 18, 2010 (Schumann et al., 2011)

Thermodynamic model HSC (at VA:VM = 5.3,

$T=890 \mathrm{~K}$ )

Kinetics model: Eyja CO (at $t=2.4 \mathrm{~s}$,

$\mathrm{VA}: \mathrm{VM}=5.3, T=890 \mathrm{~K}$ )

Kinetics model: Eyja CO- $\mathrm{H}_{2} \mathrm{~S}-\mathrm{H}_{2}$ (at $t=2.4 \mathrm{~s}$,

$\mathrm{VA}: \mathrm{VM}=5.3, T=890 \mathrm{~K}$ )

All models initialized with $\mathrm{CO} / \mathrm{SO}_{2}=0.175$.

high-temperature production of $\mathrm{SO}_{3}$ is expected as the plume cools and dilutes further. Extrapolation of Figure 5A suggests $\mathrm{SO}_{3} / \mathrm{SO}_{2}$ may potentially reach up to $\sim 2 \times 10^{-3}$. Whilst there are no reported sulfate/ $\mathrm{SO}_{2}$ measurements for the Eyjafjallajökull summit eruption for specific comparison, this modeled ratio of $\mathrm{SO}_{3} / \mathrm{SO}_{2}$ of around $10^{-3}$ lies within the range of observed near-source sulfate $/ \mathrm{SO}_{2}$ ratios, including the Eyjafjallajökull flank eruption (Figure 5B and Table 1). In contrast, calculations using the HSC thermodynamic equilibrium model at $\mathrm{VA}: \mathrm{VM}=5.3$, $T=890 \mathrm{~K}$ predict $\mathrm{SO}_{3} / \mathrm{SO}_{2}$ of around 3.1, an order of magnitude above the highest ratio of sulfate $/ \mathrm{SO}_{2}$ in the field observations, and several orders of magnitude higher than the Eyjafjallajökull observations. We conclude that the chemistry producing $\mathrm{SO}_{3}$ in the near-source volcanic plume is under kinetic rather than thermodynamic control.

\section{High-Temperature Production of Oxidants $\mathrm{HO}_{2}, \mathrm{OH}$, and $\mathrm{H}_{2} \mathrm{O}_{2}$}

High-temperature oxidants $\mathrm{HO}_{x y}\left(\mathrm{HO}_{2}, \mathrm{OH}\right.$, and $\left.\mathrm{H}_{2} \mathrm{O}_{2}\right)$ are predicted to form in the Eyjafjallajökull plume through high-temperature plume chemistry, Figures 6A,B (absolute concentrations shown). Also shown for scale is the $\mathrm{SO}_{2}$ concentration that decreases largely due to dilution. Hightemperature $\mathrm{HO}_{x y}$ reaches a maximum around $0.5 \mathrm{~s}$. $\mathrm{HO}_{x y}$ production is greater for Eyja $\mathrm{CO}-\mathrm{H}_{2}-\mathrm{H}_{2} \mathrm{~S}$ than for the Eyja CO simulation. In both cases $\mathrm{HO}_{x}$ exists predominantly as $\mathrm{HO}_{2}$. This contrasts with thermodynamic calculations that predict $\mathrm{HO}_{x}$ to exit predominantly as $\mathrm{OH}$ (e.g., Gerlach, 2004). Another important feature of the chemical kinetics modeling is that $\mathrm{H}_{2} \mathrm{O}_{2}$ is predicted to form (at greatest abundance for Eyja $\mathrm{CO}-\mathrm{H}_{2}-\mathrm{H}_{2} \mathrm{~S}$ ), whilst $\mathrm{H}_{2} \mathrm{O}_{2}$ is essentially not formed in HSC thermodynamic calculations (e.g., Martin et al., 2006).

High-temperature $\mathrm{SO}_{3}$ was discussed above as a precursor to sulfate aerosols. The $\mathrm{H}_{2} \mathrm{O}_{2}$ formed by high-temperature chemistry may promote further sulfate formation upon plume cooling, due to its reaction with dissolved $\mathrm{SO}_{2(a q)}$. If a condensed phase is formed already in the crater zone this could yield an additional source of "primary" or near-source sulfate. Alternatively, if plumes become condensed clouds further 
A

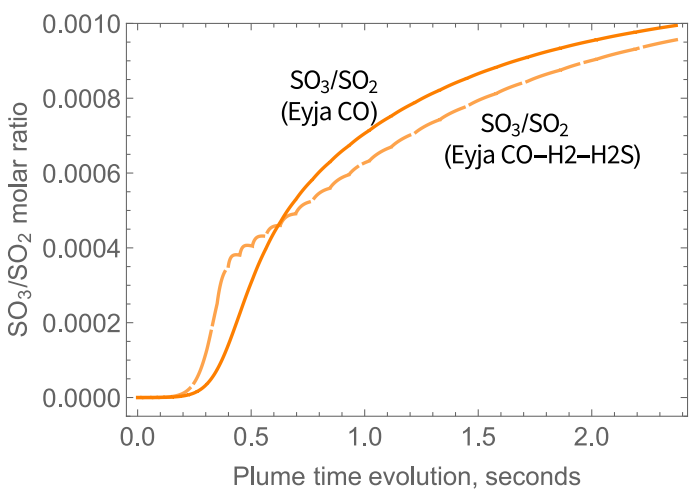

B

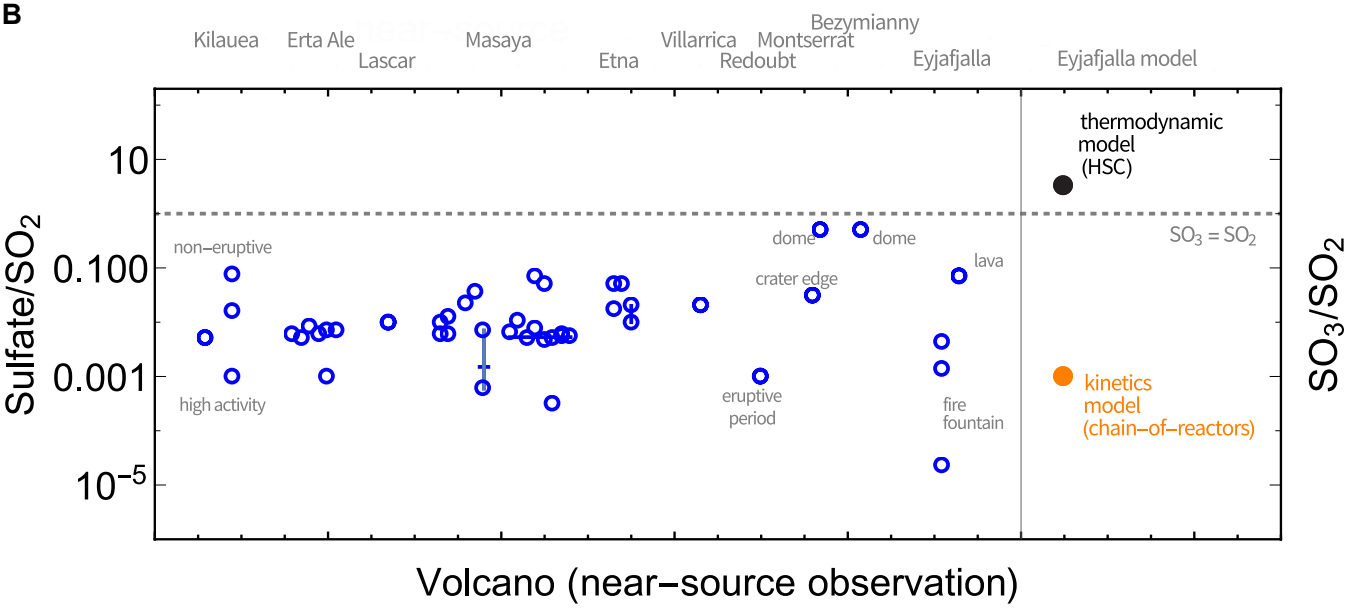

FIGURE 5 | (A) Evolution in the $\mathrm{SO}_{3} / \mathrm{SO}_{2}$ molar ratio in Eyjafjallajökull plume as a function of time, according to the chain-of-reactors model. Solid lines: Eyja CO simulation, Dashed lines: Eyja CO- $\mathrm{H}_{2}-\mathrm{H}_{2} \mathrm{~S}$ simulation. (B) Observations of near- or at-source sulfate relative to $\mathrm{SO}_{2}$ reported in volcanic plumes (Table 1) compared to the molar ratio of sulfate precursor $\mathrm{SO}_{3}$ to $\mathrm{SO}_{2}$ predicted by the chain-of-reactors model for Eyjafjallajökull eruption plume (time $=2.4 \mathrm{~s}, T=890 \mathrm{~K}, \mathrm{VA}: \mathrm{VM}=5.3$ ) and HSC thermodynamic equilibrium calculations for the same plume conditions ( $T=890 \mathrm{~K}, \mathrm{VA}: \mathrm{VM}=5.3)$. The $\mathrm{SO}_{3}=\mathrm{SO}_{2}$ is demarked by a dotted line.
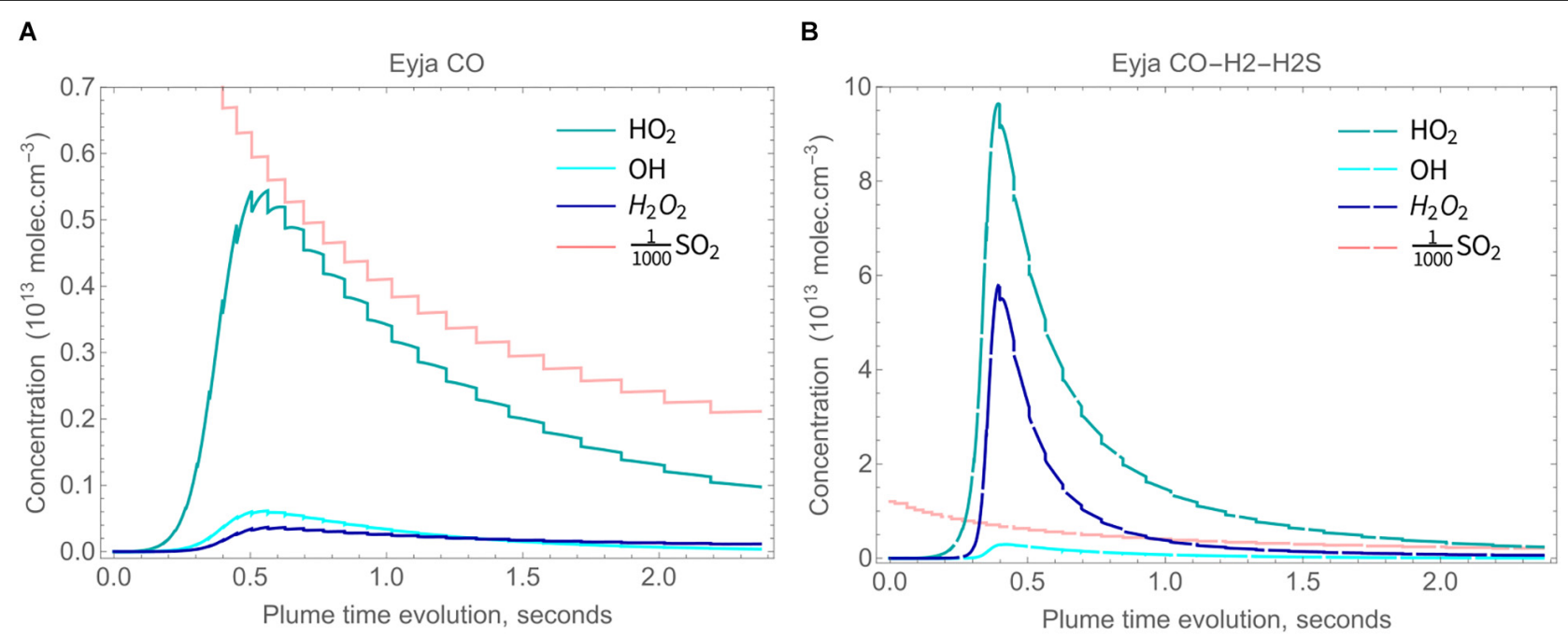

FIGURE 6 | Concentrations of $\mathrm{HO}_{2}$ (blue), $\mathrm{H}_{2} \mathrm{O}_{2}$ (dark blue) and $\mathrm{OH}$ (cyan) in the plume, with $\mathrm{SO}_{2}$ concentration also shown for scale, molec cm ${ }^{-3}$. (A) solid lines: Eyja $\mathrm{CO}$ simulation and (B) dashed lines: Eyja CO- $\mathrm{H}_{2}-\mathrm{H}_{2} \mathrm{~S}$ simulation. 


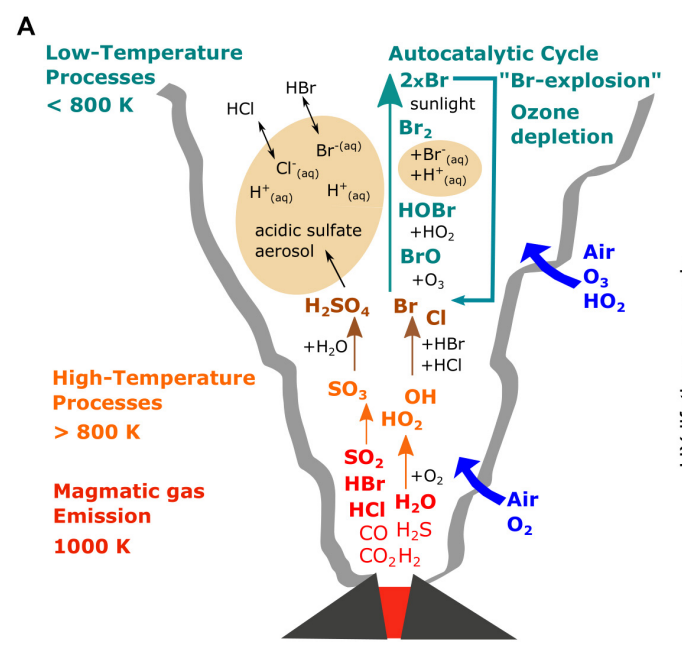

\section{B}

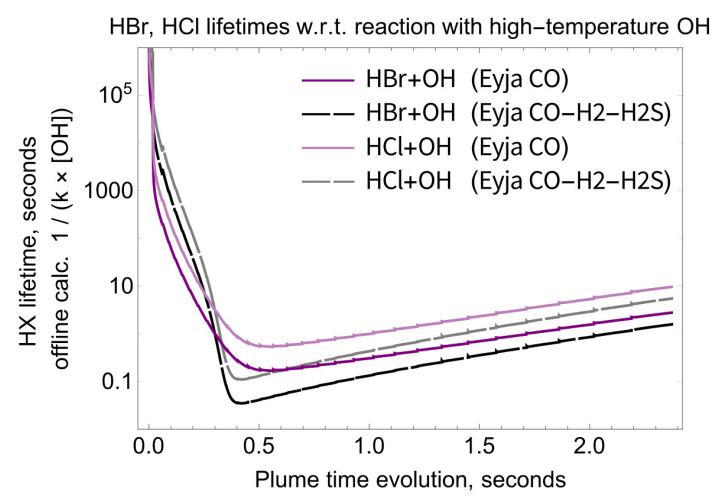

FIGURE 7 | (A) schematic of key high-to-low temperature processes in the volcanic plume, including high-temperature production of $\mathrm{SO}_{3}$ as sulfate aerosol precursor, $\mathrm{HOx}$ oxidants and halogen radicals, and low-temperature multi-phase chemistry producing $\mathrm{BrO}$. (B) Calculated lifetimes of $\mathrm{HCl}$ and $\mathrm{HBr}$ in the plume with

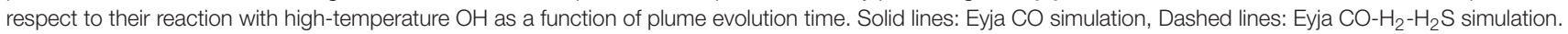
Lifetime minima are $<1 \mathrm{~s}$, see Table 4.

downwind, the volcanic $\mathrm{H}_{2} \mathrm{O}_{2}$ may form secondary sulfates. In this respect, Carn et al. (2011) measured $\mathrm{H}_{2} \mathrm{O}_{2}$ in the plume emitted by Huila volcano (elevated above background by about 0.5 ppbv) that was rapidly titrated when the plume entered a cloudy phase. We are unaware of other observations of $\mathrm{H}_{2} \mathrm{O}_{2}$ in volcanic plumes.

We highlight two further potential impacts of volcanic $\mathrm{H}_{2} \mathrm{O}_{2}$. Studies have shown that iron on the surface of volcanic ash has the potential to generate substantial quantities of hydroxyl radicals that may affect the toxicity of inhaled ash particles (Horwell et al., 2003; Hillman et al., 2012). This occurs via the Fenton reaction involving $\mathrm{H}_{2} \mathrm{O}_{2}$. The elevated abundance of $\mathrm{H}_{2} \mathrm{O}_{2}$ in the volcanic plume predicted by our model study would likely enhance the production of $\mathrm{OH}$ radicals and their potential health hazard. Indeed, an observation that has puzzled the volcanology-atmospheric community to date is the presence of elevated $\mathrm{OH}\left(\right.$ and $\mathrm{HO}_{2}$ ) measured in the $2010 \mathrm{Mt}$ Hekla eruption cloud in the stratosphere (Rose et al., 2006). This elevated $\mathrm{OH}$ is all the more surprising given the measurement was made during night-time and in the presence of major $\mathrm{OH}$ reactive sinks (e.g., $\mathrm{HCl}$ and $\mathrm{SO}_{2}$ ). We propose the reaction of volcanic $\mathrm{H}_{2} \mathrm{O}_{2}$ on ash particles as a possible mechanism that could generate $\mathrm{OH}$ radicals in volcanic plumes even during night-time.

\section{Potential for High-Temperature Formation of Halogen Radicals}

High-temperature oxidants such as $\mathrm{OH}$ and radicals such as $\mathrm{Br}$, $\mathrm{Cl}$ are believed to have an important role in accelerating the onset of low-temperature atmospheric chemistry "bromine explosion" cycles that form $\mathrm{BrO}$ and destroy ozone in the downwind plume (e.g., Bobrowski et al., 2007; Roberts et al., 2014; Surl et al., 2015; Figure 7A). The bromine explosion is autocatalytic so can be efficiently "kick-started" by a small quantity of high-temperature halogen radicals. Observations show that halogens were emitted during the eruption (young plume $\mathrm{HCl} / \mathrm{SO}_{2} \approx 0.65$, Allard et al., 2011) and that reactive halogen chemistry was active in the plume (downwind plume $\mathrm{BrO} / \mathrm{SO}_{2} \approx 1.3 \times 10^{-4}$, Heue et al., 2011). The Eyjafjallajökull volcanic halogen chemistry caused a depletion of tropospheric ozone (Vance et al., 2010; Schumann et al., 2011). Here offline calculations show the potential for formation of high-temperature halogen radicals to initiate this process.

The $\mathrm{OH}$ formed in the near-source volcanic plume is a powerful oxidant that can react with volcanic halogens (emitted as $\mathrm{HCl}$ and $\mathrm{HBr}$ ) to produce halogen radicals ( $\mathrm{R} 1$ and $\mathrm{R} 2$ ). The high-temperature chemical kinetics model scheme used in this study does not include halogen chemistry. Nevertheless, offline calculations of the lifetime of volcanic $\mathrm{HCl}, \mathrm{HBr}$ emissions can be undertaken to estimate the potential for halogen radical formation, shown here for the Eyjafjallajökull simulations.

$$
\mathrm{R} 1 \mathrm{HCl}+\mathrm{OH} \rightarrow \mathrm{Cl}+\mathrm{H}_{2} \mathrm{O}
$$

With bimolecular rate constant reported by Ravishankara et al. (1985) as $k=4.5 \times 10^{-17} \times T^{1.65} \exp [112 / T]$ $\mathrm{cm}^{3}$ molecule ${ }^{-1} \mathrm{~s}^{-1}$ (valid for $240-1055 \mathrm{~K}$ ).

$$
\mathrm{R} 2 \mathrm{HBr}+\mathrm{OH} \rightarrow \mathrm{Br}+\mathrm{H}_{2} \mathrm{O}
$$

With bimolecular rate constants estimated by Góger et al. $(2018)$ as $k=(9.86 \pm 2.38) \times 10^{-16} \times \mathrm{T}^{(1.23 \pm 0.03)} \times$ $\exp \left[(5.93 \pm 0.33) \mathrm{kJ} \mathrm{mol}^{-1} / \mathrm{RT}\right] \mathrm{cm}^{3}$ molecule $\mathrm{s}^{-1}$ (valid for $600-3200 \mathrm{~K})$.

Lifetimes of $\mathrm{HBr}$ and $\mathrm{HCl}$ in the near-source plume are calculated by the inverse of the first-order rate constant, i.e., the product of the 2nd order rate constants for R1 and R2 with the $\mathrm{OH}$ concentration. The temperature dependence of the rate constants is only slight (variation of up to about 15\%) over our studied temperature range 890-1000 K. Rather, Figure 7B shows that the calculated $\mathrm{HCl}$ and $\mathrm{HBr}$ lifetimes during the Eyja 


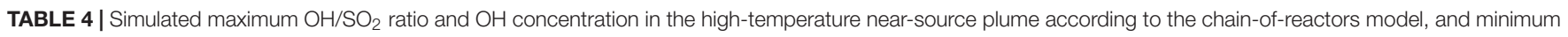
lifetime of $\mathrm{HX}(\mathrm{X}=\mathrm{Br}$ or $\mathrm{Cl})$ with respect to reaction with $\mathrm{OH}$ by offline calculation (see section "Potential for High-Temperature Formation of Halogen Radicals" and Figure 7B).

\begin{tabular}{|c|c|c|c|c|}
\hline Model run & $\begin{array}{l}\text { Maximum } \mathrm{OH} / \mathrm{SO}_{2} \\
\text { (simulated) } \mathrm{mol} / \mathrm{mol}\end{array}$ & $\begin{array}{c}\text { Maximum OH } \\
\text { concentration } \\
\text { (simulated) molec } \mathrm{cm}^{-3}\end{array}$ & $\begin{array}{c}\text { Minimum HBr lifetime } \\
\text { (offline calculation) } \\
\text { seconds }\end{array}$ & $\begin{array}{c}\text { Minimum HCl lifetime } \\
\text { (offline calculation) } \\
\text { seconds }\end{array}$ \\
\hline Eyja CO & $1.06 \times 10^{-4}$ & $6.13 \times 10^{11}$ & 0.167 & 0.534 \\
\hline Eyja CO- $\mathrm{H}_{2}-\mathrm{H}_{2} \mathrm{~S}$ & $4.38 \times 10^{-4}$ & $2.93 \times 10^{12}$ & 0.035 & 0.110 \\
\hline
\end{tabular}

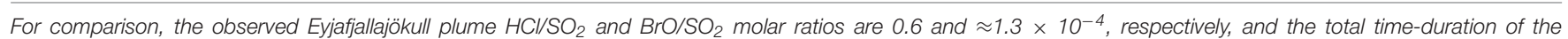
high-temperature simulation is $2.4 \mathrm{~s}$.

$\mathrm{CO}$ and Eyja $\mathrm{CO}-\mathrm{H}_{2}-\mathrm{H}_{2} \mathrm{~S}$ simulations are a strong function of $\mathrm{OH}$ concentration. The halogen halide lifetimes rapidly decrease as $\mathrm{OH}$ is formed in the near-source plume, and then increase as $\mathrm{OH}$ is consumed (and diluted). Lifetimes of $\mathrm{HBr}$ and $\mathrm{HCl}$ reach minima of $<1 \mathrm{~s}$ in the plume, Table 4 . Lifetimes are shortest for $\mathrm{HBr}$ that has the greater rate constant of reaction and for the Eyja $\mathrm{CO}-\mathrm{H}_{2}-\mathrm{H}_{2} \mathrm{~S}$ simulation that produces highest $\mathrm{OH}$ concentration. In all cases, the calculated $\mathrm{HBr}$ and $\mathrm{HCl}$ lifetime minima are shorter than the timescale of the plume simulation (2.4 s) indicating that significant halogen radical production will occur. Reactions R1 and R2 will likely cause a negative feedback on $\mathrm{OH}$ concentrations. Once formed the halogen radicals will react with $\mathrm{CHOS}$ and some may reform $\mathrm{HBr}$ or $\mathrm{HCl}$. A more comprehensive understanding of the halogen interactions will require inclusion of halogen reactions explicitly in the hightemperature model chemical mechanism.

\section{DISCUSSION}

\section{Chemical Reaction Mechanisms and Feedbacks}

The chemical kinetics model identifies key reactions causing oxidation and oxidant production in the volcanic plume. In this study, the model simulations predict abundances of oxidants, and oxidized species increase rapidly around $0.5 \mathrm{~s}$, at $T=980 \mathrm{~K}$, corresponding to $\mathrm{VA}: \mathrm{VM}$ around 1 according to the specific Eyjafjallajökull boundary conditions scenario used (different times or temperature conditions can be expected under other plume dyamics conditions). VA:VM = around 1 corresponds to the point where mixing of magmatic gases and air yields a maximum in the product of air-derived $\mathrm{O}_{2}$ and magmaticderived $\mathrm{H}_{2} \mathrm{O}$. Radical oxidants $\mathrm{HO}_{x}$ are produced from the reaction of $\mathrm{H}_{2} \mathrm{O}$ with $\mathrm{O}_{2}$ to form $\mathrm{OH}$ and $\mathrm{HO}_{2}, \mathrm{R} 3$. This (twoway) reaction usually acts as a sink rather than source of radicals in combustion but $\mathrm{OH}$ and $\mathrm{HO}_{2}$ formation in the near-source volcanic plume is driven by the unusually high $\mathrm{H}_{2} \mathrm{O}$ content of the plume-air mixture at high temperatures. Production of $\mathrm{HO}_{x}$ is fastest at around $0.5 \mathrm{~s}$ or $\mathrm{VA}: \mathrm{VM}=1$, coincident with the maximum in the product of $\mathrm{H}_{2} \mathrm{O}$ and $\mathrm{O}_{2}$ mole fractions.

$$
\text { R3 } \mathrm{H}_{2} \mathrm{O}+\mathrm{O}_{2} \rightleftharpoons \mathrm{OH}+\mathrm{HO}_{2}
$$

Formation of $\mathrm{SO}_{3}$ occurs by the reaction $\mathrm{R} 4$ of $\mathrm{SO}_{2}$ with $\mathrm{HO}_{2}$.

$$
\mathrm{R} 4 \mathrm{SO}_{2}+\mathrm{HO}_{2} \rightleftharpoons \mathrm{SO}_{3}+\mathrm{OH}
$$

When CO is present in the plume, some of it can react with $\mathrm{OH}$ to form $\mathrm{CO}_{2}$ and $\mathrm{H}$ radicals, $\mathrm{R} 5$, which may further react with $\mathrm{O}_{2}$ to form $\mathrm{HO}_{2}$, R6.

$$
\begin{array}{r}
\mathrm{R} 5 \mathrm{CO}+\mathrm{OH} \rightleftharpoons \mathrm{CO}_{2}+\mathrm{H} \\
\mathrm{R} 6 \mathrm{H}+\mathrm{O}_{2}+\mathrm{M} \rightleftharpoons \mathrm{HO}_{2}+\mathrm{M}
\end{array}
$$

Once formed, $\mathrm{HO}_{2}$ can react with itself, $\mathrm{R} 7$, to produce hydrogen peroxide, $\mathrm{H}_{2} \mathrm{O}_{2}$.

$$
\text { R7 } \mathrm{HO}_{2}+\mathrm{HO}_{2} \rightleftharpoons \mathrm{H}_{2} \mathrm{O}_{2}+\mathrm{O}_{2}
$$

Some $\mathrm{H}_{2} \mathrm{O}_{2}$ can also thermally decompose to form $\mathrm{OH}$ radicals, $\mathrm{R} 8$.

$$
\mathrm{R} 8 \mathrm{H}_{2} \mathrm{O}_{2}+\mathrm{M} \rightleftharpoons \mathrm{OH}+\mathrm{OH}+\mathrm{M}
$$

In high-temperature chemistry (generally temperatures above $800-850 \mathrm{~K}$ ), formation of $\mathrm{H}_{2} \mathrm{O}_{2}$ is usually considered as a sink of oxidant radicals. However, in the case of a near-source plume the removal of $\mathrm{OH}$ by $\mathrm{CO}$ ( $\mathrm{R} 5$, followed by $\mathrm{R} 6$ and $\mathrm{R} 7$ leading to $\mathrm{H}_{2} \mathrm{O}_{2}$ ) drives the formation of more $\mathrm{OH}$ and $\mathrm{HO}_{2}$ from the reaction of $\mathrm{H}_{2} \mathrm{O}$ with $\mathrm{O}_{2}$ (more specifically, the balance of this reaction, $\mathrm{R} 3$, with its reverse reaction). This feedback mechanism promotes the production of $\mathrm{HO}_{x y}$ in volcanic plumes containing $\mathrm{CO}$, where only a fraction of the emitted $\mathrm{CO}$ needs to be oxidized to substantially enhance $\mathrm{HO}_{x y}$ abundances and promote the chain reaction. Similarly, the $\mathrm{H}_{2}$ emission in the Eyja $\mathrm{CO}-\mathrm{H}_{2}-$ $\mathrm{H}_{2} \mathrm{~S}$ simulation can also react with $\mathrm{OH}$, R9 (followed by R6 and R7) to cause a similar positive feedback on $\mathrm{HO}_{x}$ production.

$$
\text { R9 } \mathrm{H}_{2}+\mathrm{OH} \rightleftharpoons \mathrm{H}_{2} \mathrm{O}+\mathrm{H}
$$

These feedbacks involving reduced gases may explain the greater production of oxidants in Eyja $\mathrm{CO}-\mathrm{H}_{2}-\mathrm{H}_{2} \mathrm{~S}$ than Eyja $\mathrm{CO}$ simulation. This hypothesis is supported by a sensitivity study without $\mathrm{CO}$ and $\mathrm{SO}_{2}$ in the emission (Eyja no-CO no$\mathrm{SO}_{2}$, Supplementary Figure S2) that produces a lower $\mathrm{OH}$ abundance but where more $\mathrm{OH}$ accumulates more in the first hundreds of milliseconds, reflecting the balance of $\mathrm{OH}$ production and consumption.

We now consider the role of $\mathrm{H}_{2} \mathrm{~S}$. The very low (theoretically estimated) $\mathrm{H}_{2} \mathrm{~S}$ emission from Eyjafjallajökull had a rather negligible impact on the near-source plume chemistry. The role of $\mathrm{H}_{2} \mathrm{~S}$ is investigated in a simulation of the high-temperature chemistry of Mt Etna emissions, that include $\mathrm{H}_{2}$ and $\mathrm{H}_{2} \mathrm{~S}$ as well as $\mathrm{SO}_{2}, \mathrm{H}_{2} \mathrm{O}$, and $\mathrm{CO}_{2}$, see Supplementary Table S4 (as well as 
a control run that excludes $\mathrm{H}_{2} \mathrm{~S}$ ). The Etna simulation assumes an eruption with the same plume physics as for Eyjafjallajökull. A very rapid production of oxidants is predicted within the first 0.1 s of plume evolution, Supplementary Figure S3, coincident with a rapid decrease in $\mathrm{H}_{2} \mathrm{~S}$ (and a slower decrease in $\mathrm{H}_{2}$ ). Abundances of oxidant radicals initially substantially exceed those predicted for Eyja $\mathrm{CO}$ and Eyja $\mathrm{CO}-\mathrm{H}_{2}-\mathrm{H}_{2} \mathrm{~S}$, and later decline to lower levels. According to our model, the oxidation of emitted $\mathrm{H}_{2} \mathrm{~S}$ causes an extra production of $\mathrm{O}$ atoms (which is not observed in the case "without $\mathrm{H}_{2} \mathrm{~S}$ ") with in the first milliseconds of the plume's mixing with air, following the sequence: $\mathrm{H}_{2} \mathrm{~S}+\mathrm{H}$ (or $\mathrm{OH})=\mathrm{SH}+\mathrm{H}_{2}$ (or $\mathrm{H}_{2} \mathrm{O}$ ), $2 \mathrm{SH}=\mathrm{H}_{2} \mathrm{~S}+\mathrm{S}, \mathrm{S}+\mathrm{O}_{2}=\mathrm{SO}+$ $\mathrm{O}$, and $\mathrm{SO}+\mathrm{O}_{2}=\mathrm{SO}_{2}+\mathrm{O}$. The production of sulfur atoms from $\mathrm{H}_{2} \mathrm{~S}$ and their subsequent reactions with $\mathrm{O}_{2}$ are mostly responsible for this production of $\mathrm{O}$, which, in turn, converts $\mathrm{SO}_{2}$ into $\mathrm{SO}_{3}$, resulting in the $\mathrm{SO}_{3}$ peak observed at $0.1 \mathrm{~s}$ in the plume. Beyond this point, the conversion of $\mathrm{SO}_{2}$ into $\mathrm{SO}_{3}$ is mainly due to the abundance of $\mathrm{HO}_{2}$ through $\mathrm{SO}_{2}+\mathrm{HO}_{2}=\mathrm{SO}_{3}$ + OH. A significant part of $\mathrm{SO}_{3}$ is then used to recycle $\mathrm{SO}_{2}$ through the formation of $\mathrm{HOSO}_{2}\left(\mathrm{SO}_{3}+\mathrm{HO}_{2}=\mathrm{HOSO}_{2}+\mathrm{O}_{2}\right.$ and $\left.\mathrm{HOSO}_{2}+\mathrm{M}=\mathrm{SO}_{2}+\mathrm{OH}+\mathrm{M}\right)$. Indeed, the formation of $\mathrm{SO}_{3}$ in the Mt Etna scenario proceeds through two different mechanisms (with $\mathrm{O}$, and then with $\mathrm{HO}_{2}$ ) at different locations in the plume whereas in the Eyja $\mathrm{CO}$ and Eyja CO- $\mathrm{H}_{2}-\mathrm{H}_{2} \mathrm{~S}$ or Etna no- $\mathrm{H}_{2} \mathrm{~S}$ scenarios, the formation of $\mathrm{SO}_{3}$ is only linked to $\mathrm{HO}_{2}$. It must be emphasized, however, that model predictions are limited by uncertainty in high-temperature $\mathrm{H}_{2} \mathrm{~S}$ chemistry.

This sulfur cycling regulates $\mathrm{SO}_{3} / \mathrm{SO}_{2}$ to reach around $10^{-3}$ after $2.4 \mathrm{~s}$ in all of the simulations (Eyja $\mathrm{CO}$, Eyja $\mathrm{CO}-\mathrm{H}_{2}-\mathrm{H}_{2} \mathrm{~S}$, Etna and Etna no- $\mathrm{H}_{2} \mathrm{~S}$, Figure $\mathbf{5 A}$ and Supplementary Figure S3), despite their differences in $\mathrm{CO}-\mathrm{H}_{2}$ $\mathrm{H}_{2} \mathrm{~S}$ emissions that lead to vast differences in the production and abundances of $\mathrm{HO}_{x y}$. Temperature and VA:VM evolution with time may be important controls on $\mathrm{SO}_{3} / \mathrm{SO}_{2}$, therefore production of near-source sulfate could vary for different physical conditions other than the Eyjafjallajökull case considered here.

\section{Model Uncertainties and Future Directions}

Our chain-of-reactors model provides a framework for quantitative studies into the high-temperature reactions occurring in the near-source plume to form oxidized products such as sulfate-precursors, $\mathrm{OH}, \mathrm{H}_{2} \mathrm{O}_{2}$ that can impact subsequent physico-chemical processing in the cooled plume. We find that the high-temperature chemistry is under kinetic control; plume composition does not follow thermodynamic equilibrium (Figures 4A, 5B, with example model output in Supplementary Tables S5, S6). Our exploratory study identifies several areas for further investigation.

\section{Improved Model Chemistry at High-Temperatures and Link to Low-Temperature Plume Processes}

Uncertainties in the high-temperature gas chemistry mechanism need to be addressed such as the chemical kinetics of sulfur species reactions, notably the oxidation of $\mathrm{H}_{2} \mathrm{~S}$, that are poorly quantified from laboratory experiments. Future model developments should also incorporate the chemistry of halogens and nitrogen species coupled to CHOS. Simulations of longer duration should cover the whole regime where high-temperature chemical reactions may be important (e.g., down to 800/850 K). The gas-phase mechanism should be extended to consider photolysis reactions for plumes that are not too optically thick, and, especially, heterogeneous chemical reactions, for example reactions on ash surfaces (Delmelle et al., 2018), noting the oxidized products from high-temperature gas chemistry could act to modify ash properties. Models should ultimately be developed that encompass both high-temperature chemistry and also the transition to low-temperature plume chemistry as simulated by atmospheric models (e.g., Jourdain et al., 2016).

\section{Influence of Emitted Magmatic Gas Composition on High-Temperature Chemistry}

The composition of magmatic gases released is specific to each volcano and can vary with volcanic activity/unrest. The chemical feedback mechanisms identified by our model suggest that emissions of reduced gases can enhance the high-temperature production of oxidants. This might lead to a greater production of oxidant radicals in the near-source plume of volcanoes with a relatively reduced emissions composition, such as Mt Erebus, Antarctica, whose emissions are rich in $\mathrm{CO}$ and $\mathrm{H}_{2}$. Few field-measurements exist to evaluate model predictions: the high-temperature region is difficult to access directly and few studies have quantified oxidized products in the cooled downwind plume, e.g., by instrumented aircraft. Another critical uncertainty is that the emission temperature of volcanic gases is poorly known. In some situations, according to the dynamics of the degassing, magmatic gas emissions at the surface may be neither in chemical nor thermodynamic equilibrium with the melt (Oppenheimer et al., 2018).

\section{Influence of Plume Dynamics on High-Temperature Chemistry}

The chemical kinetics model requires time-resolved boundary conditions in plume dynamics, notably temperature and VA:VM (degree of mixing of air with magmatic gases). This study used output from a 1D PlumeRise model for the Eyjafjallajökull 2010 eruption (Woodhouse et al., 2013) for this purpose. Variability in plume dynamics was not investigated but is expected to exert a strong influence on the near-source chemistry through the rate of entrainment of air and cooling. For example, smaller emission sources will typically disperse and cool faster in the troposphere. Ash-poor emissions will tend to cool more rapidly than ash-rich emissions where the solid pyroclasts buffer the temperature of the volcanic gas and air mixture. Large eruptions that inject gases and ash into the stratosphere should also be investigated. Spatial heterogeneity in the turbulent mixing of air into the plume might nonlinearly impact the plume chemistry, potentially requiring the development of 3D model approaches to investigate the plume's high-temperature chemistry as a function of a more detailed turbulent mixing. 


\section{CONCLUSIONS}

We present chemical kinetics model simulations of the hightemperature gas chemistry that occurs as magmatic gases mix with air and cool in the near-source volcanic plume. Volcanic gases released into the atmosphere undergo rapid processing including photochemistry, oxidation, and aerosol formation. Quantifying these processes in volcanic plumes is essential to assess atmospheric and environmental impacts of volcanic emissions. During the first few seconds after release, the hot magmatic gases mix with background air containing oxidants and undergo a high-temperature processing. The gas chemistry in this high-temperature region of the plume is poorly characterized, yet can critically modify the composition of the emission to produce oxidized products and radicals, such as near-source sulfates, HOxy, and halogen radicals. These high-temperature products influence the subsequent physico-chemical processing of the plume at low-temperatures as it disperses in the atmosphere. Studies to date have largely represented the chemical composition of the high-temperature region using thermal equilibrium calculations (e.g., Martin et al., 2006; Hoshyaripour et al., 2012). A source of uncertainty in thermodynamic modeling of the hightemperature chemistry of volcanic plumes is the assumption of equilibrium conditions, that may not always be valid for transient plumes (Martin et al., 2009).

The chain-of-reactors approach of this study is timeresolved and based on chemical kinetics thus differs markedly from thermodynamic equilibrium calculations used to date. We performed an exploratory study of the high-temperature chemistry in a near-source volcanic plume over the first $2.4 \mathrm{~s}$, using as boundary conditions for the time-varying temperature and mixing of air output from 1D PlumeRise model simulations of Eyjafjallajökull plume (Woodhouse et al., 2013). The magmatic gas emission includes $\mathrm{H}_{2} \mathrm{O}, \mathrm{CO}_{2}, \mathrm{SO}_{2}$, and $\mathrm{CO}$, based on observations of the young plume (Allard et al., 2011), with theoretical estimates for $\mathrm{H}_{2} \mathrm{~S}$ and $\mathrm{H}_{2}$ gas emissions added in a sensitivity study and offline calculations performed for halogens.

A key finding is that the plume chemistry is under kinetic control and that thermodynamic equilibrium cannot be assumed. The simulation predicts that $\mathrm{CO}$ emission from Eyjafjallajökull is not fully oxidized (largely conserved) by high-temperature chemistry. This is consistent with field-observations of $\mathrm{CO}$ in the volcanic plume (Allard et al., 2011; Schumann et al., 2011) and contrasts to thermal equilibrium calculations of near-complete $\mathrm{CO}$ oxidation, Table 3. Instead, our study shows $\mathrm{CO}$ oxidation is under chemical kinetics control. The model predicts that sulfateprecursor $\mathrm{SO}_{3}$ is formed at levels $\left(\mathrm{SO}_{3} / \mathrm{SO}_{2}=10^{-3}\right)$ in general agreement to observations of near-source volcanic sulfate $/ \mathrm{SO}_{2}$ in volcanic plumes, Table 1. Conversely, thermodynamic calculations predict a much greater formation of $\mathrm{SO}_{3}$ relative to $\mathrm{SO}_{2}$ for the same plume dynamics conditions. The kinetics

\section{REFERENCES}

Aiuppa, A., Franco, A., von Glasow, R., Allen, A. G., D’Alessandro, W., Mather, T. A., et al. (2007). The tropospheric processing of acidic gases and hydrogen model predicts high-temperature formation of $\mathrm{HO}_{2}, \mathrm{OH}$, and $\mathrm{H}_{2} \mathrm{O}_{2}$. Formation of $\mathrm{HO}_{x y}$ is predicted to be enhanced when additional reduced gases $\left(\mathrm{H}_{2} \mathrm{~S}\right.$ and $\left.\mathrm{H}_{2}\right)$ besides $\mathrm{CO}$ are included in the emission.

Offline calculations demonstrate that volcanic halogens $(\mathrm{HBr}$ and $\mathrm{HCl})$ will react rapidly with high-temperature $\mathrm{OH}$, highlighting the potential for halogen radicals to form in the high-temperature plume. A key chemical mechanism is that $\mathrm{HO}_{x}$ oxidants are formed by the (reversible) reaction of $\mathrm{H}_{2} \mathrm{O}$ with $\mathrm{O}_{2}$ at high-temperatures to produce $\mathrm{OH}$ and $\mathrm{HO}_{2}$. Chemical feedbacks occur when reduced gases in the volcanic emission ( $\mathrm{CO}$ and $\mathrm{H}_{2}$ ) react with $\mathrm{OH}$ to produce $\mathrm{HO}_{2}$ that can selfreact to form $\mathrm{H}_{2} \mathrm{O}_{2}$. Thus reduced gases in the volcanic emission act to promote formation of high-temperature $\mathrm{HO}_{x y}$. Another chemical feedback occurs via the oxidation pathway for volcanic $\mathrm{H}_{2} \mathrm{~S}$ that rapidly generates additional oxidants in a chainreaction. However, there is large uncertainty in some hightemperature reactions, particularly for sulfur species. Quantifying the chemical processes occurring at high-temperatures in the near-source plume is an essential step in understanding the reactivity and evolution of volcanic emissions and their impacts in the troposphere and stratosphere. Improved characterization of this high-temperature region of the plume will require the combination of model, field-observation and laboratory studies.

\section{AUTHOR CONTRIBUTIONS}

All authors contributed to the study design, analysis and interpretation of data, and manuscript writing.

\section{ACKNOWLEDGMENTS}

We are grateful to the reviewers for their comments on the original manuscript. TR acknowledges support from the ANR Projet de Recherche Collaborative VOLC-HAL-CLIM (Volcanic Halogens: from Deep Earth to Atmospheric Impacts), ANR-18CE01-0018, and Labex Orléans Labex VOLTAIRE (VOLatilsTerre Atmosphère Interactions - Ressources et Environnement, ANR-10-LABX-100-0). GD and CO acknowledge support from the Orléans Labex Caprysses (convention ANR-11-LABX-000601) and the NERC Centre for Observation and Modelling of Earthquakes, Volcanoes, and Tectonics (COMET), respectively.

\section{SUPPLEMENTARY MATERIAL}

The Supplementary Material for this article can be found online at: https://www.frontiersin.org/articles/10.3389/feart. 2019.00154/full\#supplementary-material

sulphide in volcanic gas plumes as inferred from field and model investigations. Atmos. Chem. Phys. 7, 1441-1450. doi: 10.5194/acp-7-1441-2007

Aiuppa, A., Inguaggiato, S., McGonigle, A. J. S., O’Dwyer, M., Oppenheimer, C., Padgett, M. J., et al. (2005). H2S fluxes from Mt. Etna, Stromboli, and 
Vulcano (Italy) and implications for the sulfur budget at volcanoes. Geochim. Cosmochim. Acta 69, 1861-1871. doi: 10.1016/j.gca.2004.09.018

Aiuppa, A., Shinohara, H., Tamburello, G., Giudice, G., Liuzzo, M., and Moretti, R. (2011). Hydrogen in the gas plume of an open-vent volcano, Mount Etna, Italy. J. Geophys. Res. 116, B10204. doi: 10.1029/2011JB008461

Allard, P., Burton, M., Oskarsson, N., Michel, A., and Polacci, M. (2011). Magmatic gas composition and fluxes during the 2010 Eyjafjallajökull explosive eruption: implications for degassing magma volumes and volatile sources. Geophys. Res. Abstracts 13:EGU2011-12040-1.

Allen, A. G., Baxter, P. J., and Ottley, C. J. (2000). Ottley, Gas and particle emissions from Soufrière Hills Volcano, Montserrat, West Indies: characterization and health hazard assessment. Bull. Volcanol. 62, 8-19. doi: 10.1007/s004450 050287

Allen, A. G., Oppenheiler, C., Ferm, M., Baxter, P. J., Horrocks, L. A., Galle, B., et al. (2002). Primary sulfate aerosol and associated emissions from Masaya, Volcano, Nicaragua. J. Geophys. Res. 107, ACH5-1-ACH5-8. doi: 10.1029/2002 JD002120

Aubry, T. J., Carazzo, G., and Jellinek, A. M. (2017). Turbulent entrainment into volcanic plumes: new constraints from laboratory experiments on buoyant jets rising in a stratified crossflow. Geophys. Res. Lett. 44, 198-110. doi: 10.1002/ 2017GL075069

Bobrowski, N., von Glasow, R., Aiuppa, A., Inguaggiato, S., Louban, I., Ibrahim, O. W., et al. (2007). Reactive halogen chemistry in volcanic plumes. J. Geophys. Res. 112:D06311. doi: 10.1029/2006JD007206

Bobrowski, N., von Glasow, R., Giuffrida, G. B., Tedesco, D., Aiuppa, A., Yalire, M., et al. (2015). Gas emission strength and evolution of the molar ratio of $\mathrm{BrO} / \mathrm{SO} 2$ in the plume of Nyiragongo in comparison to Etna. J. Geophys. Res. Atmos. 120, 277-291. doi: 10.1002/2013JD021069

Boichu, M., Menut, L., Khvorostyanov, D., Clarisse, L., Clerbaux, C., Turquety, S., et al. (2013). Inverting for volcanic SO2 flux at high temporal resolution using spaceborne plume imagery and chemistry-transport modelling: the 2010 Eyjafjallajökull eruption case study. Atmos. Chem. Phys. 13, 8569-8584. doi: 10.5194/acp-13-8569-2013

Boichu, M., Oppenheimer, C., Roberts, T. J., Tsanev, V., and Kyle, P. (2011). On bromine, nitrogen oxides and ozone depletion in the tropospheric plume of Erebus volcano (Antarctica). Atmos. Environ. 45, 3856-3866. doi: 10.1016/j. atmosenv.2011.03.027

Branan, Y. K., Harris, A., Watson, I. M., Phillips, J. C., Horton, K., Williams-Jones, G., et al. (2008). Investigation of at-vent dynamics and dilution using thermal infrared radiometers at Masaya volcano, Nicaragua. J. Volcanol. Geothermal Res. 169, 34-47. doi: 10.1016/j.jvolgeores.2007.07.021

Carn, S. A., Froyd, K. D., Anderson, B. E., Wennberg, P., Crounse, J., Spencer, K., et al. (2011). In situ measurements of tropospheric volcanic plumes in Ecuador and Colombia during TC4. J. Geophys. Res. 116:D00J24. doi: 10.1029/ 2010JD014718

de Moor, J. M., Aiuppa, A., Avard, G., Wehrmann, H., Dunbar, N., Muller, C., et al. (2016). Turmoil at Turrialba Volcano (Costa Rica): degassing and eruptive processes inferred from high-frequency gas monitoring. J. Geophys. Res.121, 5761-5775. doi: 10.1002/2016JB013150

de Moor, J. M., Fischer, T. P., Sharp, Z. D., King, P. L., Wilke, M., Botcharnikov, R. E., et al. (2013). Sulfur degassing at Erta Ale (Ethiopia) and Masaya (Nicaragua) volcanoes: implications for degassing processes and oxygen fugacity of basaltic systems. Geochem. Geophys. Geosyst. 14, 4076-4108. doi: $10.1002 /$ ggge.20255

Delmelle, P., Wadsworth, F. B., Maters, E. C., and Ayris, P. M. (2018). High temperature reactions between gases and ash particles in volcanic eruption plumes. Rev. Mineral. Geochem. 84, 285-308. doi: 10.2138/rmg.2018.84.8

Donovan, A., Tsanev, V., Oppenheimer, C., and Edmonds, M. (2014). Reactive halogens ( $\mathrm{BrO}$ and $\mathrm{OClO})$ detected in the plume of Soufrière Hills Volcano during an eruption hiatus. Geochem. Geophys. Geosyst. 15, 3346-3363. doi: 10.1002/2014GC005419

Galeazzo, T., Bekki, S., Martin, E., Savarino, J., and Arnold, S. R. (2018). Photochemical box-modelling of volcanic $\mathrm{SO} 2$ oxidation: isotopic constraints. Atmos. Chem. Phys. Discuss. 18, 17909-17931. doi: 10.5194/acp-2018-381

Gerlach, T. M. (2004). Volcanic sources of tropospheric ozone-depleting trace gases. Geochem. Geophys. Geosyst. 5:Q09007. doi: 10.1029/2004GC000747

Glarborg, P., and Marshall, P. (2013). Oxidation of reduced sulfur species: carbonyl sulfide. Int. J. Chem. Kinet. 45, 429-439. doi: 10.1002/kin.20778
Góger, S., Szabó, P., Czakó, G., and Lendvay, G. (2018). Flame inhibition chemistry: rate coefficients of the reactions of $\mathrm{HBr}$ with $\mathrm{CH} 3$ and $\mathrm{OH}$ radicals at high temperatures determined by quasiclassical trajectory calculations. Energy Fuels 32, 10100-10105. doi: 10.1021/acs.energyfuels.8b00989

Guttmann, A., Bobrowski, N., Roberts, T. J., Rudiger, J., and Hoffman, T. (2018). Advances in bromine speciation in volcanic plumes. Front. Earth Sci. 6:213. doi: $10.3389 /$ feart.2018.00213

Heue, K.-P., Brenninkmeijer, C. A. M., Baker, A. K., Rauthe-Schöch, A., Walter, D., Wagner, T., et al. (2011). SO2 and $\mathrm{BrO}$ observation in the plume of the Eyjafjallajökull volcano 2010: CARIBIC and GOME-2 retrievals. Atmos. Chem. Phys. 11, 2973-2989. doi: 10.5194/acp-11-2973-2011

Hillman, S. E., Horwell, C., Densmore, A. L., Damby, D. E., Fubini, B., Ishimine, Y., et al. (2012). Sakurajima volcano: a physico-chemical study of the health consequences of long-term exposure to volcanic ash. Bull. Volcanol. 74, 913-930. doi: 10.1007/s00445-012-0575-3

Hobbs, P. V., Radke, L. F., Lyons, J. H., Ferek, R. J., Coffman, D. J., and Casadevall, T. J. (1991). Casadevall, Airborne measurements of particle and gas emissions from the 1990 volcanic eruptions of Mount Redoubt. J. Geophys. Res. 96, $18735-18752$.

Hörmann, C., Sihler, H., Bobrowski, N., Beirle, S., Penning de Vries, M., Platt, U., et al. (2013). Systematic investigation of bromine monoxide in volcanic plumes from space by using the GOME-2 instrument. Atmos. Chem. Phys. 13, 4749-4781. doi: 10.5194/acp-13-4749-2013

Horwell, C., Fenoglio, I., Ragnarsdottir, K. V., Sparks, R. S. J., and Fubini, B. (2003). Surface reactivity of volcanic ash from the eruption of Soufrière Hills volcano, Montserrat, West Indies with implications for health hazards. Environ. Res. 93, 202-215. doi: 10.1016/s0013-9351(03)00044-6

Hoshyaripour, G. A., Hort, M., and Langmann, B. (2012). How does the hot core of a volcanic plume control the sulfur speciation in volcanic emission? Geochem. Geophys. Geosyst. 13:Q07004. doi: 10.1029/2011GC004020

Hoshyaripour, G. A., Hort, M., and Langmann, B. (2015). Ash iron mobilization through physicochemical processing in volcanic eruption plumes: a numerical modeling approach. Atmos. Chem. Phys. 15, 9361-9379. doi: 10.5194/acp-159361-2015

Ilyinskaya, E., Martin, R., and Oppenheimer, C. (2012). Aerosol formation in basaltic lava fountaining: eyjafjallajökull volcano, Iceland. J. Geophys. Res. Atmos. 117:D00U27. doi: 10.1029/2011JD016811

Jourdain, L., Roberts, T. J., Pirre, M., and Josse, B. (2016). Modeling the reactive halogen plume from Ambrym volcano and its impact on the troposphere with the CCATT-BRAMS mesoscale model. Atmos. Chem. Phys. 16, 12099-12125. doi: 10.5194/acp-16-12099-2016

Kee, R. J., Rupley, F. M., Miller, J. A., Coltrin, M. E., Grcar, J. F., Meeks, E., et al. (2000). CHEMKIN Collection, Release 3.6. San Diego, CA: Reaction Design. Inc.

Keiding, J. K., and Sigmarsson, O. (2012). Geothermobarometry of the 2010 Eyjafjallajökull eruption: new constraints on Icelandic magma plumbing systems. J. Geophys. Res. 117:B00C09. doi: 10.1029/2011JB00 8829

Kern, C., and Lyons, J. J. (2018). Spatial distribution of halogen oxides in the plume of Mount Pagan Volcano, Mariana Islands. Geophys. Res. Lett. 45, 9588-9596. doi: 10.1029/2018GL079245

Kroll, J. H., Cross, E. S., Hunter, J. F., Pai, S., Wallace, L. M. M., Croteau, P. I., et al. (2015). Atmospheric evolution of sulfur emissions from Kilauea: reattime measurements of oxidation, dilution, and neutralization within a volcanic plume. Environ. Sci. Technol. 49, 4129-4137. doi: 10.1021/es506119x

Martin, R. S., and Ilyinskaya, E. (2011). Volcanic lightning as a source of reactive radical species in eruption plumes. Geochem. Geophys. Geosyst. 12:Q03002. doi: 10.1029/2010GC003420

Martin, R. S., Ilyinskaya, E., and Oppenheimer, C. (2012). The enigma of reactive nitrogen in volcanic emissions. Geochim. Cosmochim. Acta 95, 93-105. doi: 10.1016/j.gca.2012.07.027

Martin, R. S., Mather, T. A., and Pyle, D. M. (2006). High-temperature mixtures of magmatic and atmospheric gases. Geochem. Geophys. Geosyst. 7:Q04006. doi: 10.1029/2005GC001186

Martin, R. S., Mather, T. A., and Pyle, D. M. (2007). Volcanic emissions and the early earth atmosphere. Geochim. Cosmochim. Acta 71, 3673-3685.

Martin, R. S., Mather, T. A., Pyle, D. M., Power, M., Allen, A. G., Aiuppa, A., et al. (2008). Composition-resolved size distributions of volcanic aerosols in the Mt. Etna plumes. J. Geophys. Res. 113:D17211. doi: 10.1029/2007JD009648 
Martin, R. S., Robert, T. J., Mather, T. A., and Pyle, D. M. (2009). The implications of H2S and $\mathrm{H} 2$ kinetic stability in high-T mixtures of magmatic and atmospheric gases for the production of oxidized trace species (e.g., BrO and NOx). Chem. Geol. 263, 143-150. doi: 10.1016/j.chemgeo.2008. 12.028

Martin, R. S., Sawyer, G. M., Spanpinato, L., Salerno, G. G., Ramirez, C., Ilyinskaya, E., et al. (2010). A total volatile inventory for Masaya Volcano, Nicaragua. J. Geophys. Res. 115:B09215. doi: 10.1029/2010JB007480

Martin, R. S., Witt, M. L. I., Pyle, D. M., Mather, T. A., Watt, S. F. L., Bagnato, E., et al. (2011). Rapid oxidation of mercury $(\mathrm{Hg})$ at volcanic vents: insights from high temperature thermodynamic models of Mt Etna's emissions. Chem. Geol. 283, 279-286. doi: 10.1016/j.chemgeo.2011.01.027

Mastin, L. G. (2007). A user-friendly one-dimensional model for wet volcanic plumes. Geochem. Geophys. Geosyst. 8:Q03014. doi: 10.1029/2006GC0 01455

Mather, T. A., Allen, A. G., Davison, B. M., Pyle, D. M., Oppenheimer, C., and McGonigle, A. J. S. (2004a). Nitric acid from volcanoes. Earth Planet. Sci. Lett. 218, 17-30. doi: 10.1016/s0012-821x(03)00640-x

Mather, T. A., Allen, A. G., Oppenheimer, C., Pyle, D. M., and McGonigle, A. J. S. (2003). Size-resolved characterisation of soluble ions in the particles in the tropospheric plume of Masaya Volcano, Nicaragua: origins and plume processing. J. Atmos. Chem. 46, 207-237.

Mather, T. A., Tsanev, V. I., Pyle, D. M., McGonigle, A. J. S., Oppenheimer, C., and Allen, A. G. (2004b). Characterization and evolution of tropospheric plumes from Lascar and Villarrica volcanoes, Chile. J. Geophys. Res. Atmos. 109:D21303. doi: 10.1029/2004JD004934

Mathieu, O., Mulvihill, C., and Petersen, E. L. (2017). Shock-tube water timehistories and ignition delay time measurements for $\mathrm{H} 2 \mathrm{~S}$ near atmospheric pressure. Proc. Combust. Inst. 36, 4019-4027. doi: 10.1016/j.proci.2016. 06.027

Moussallam, Y., Oppenheimer, C., Aiuppa, A., Gaetano, G., Moussallam, M., and Kype, P. (2012). Hydrogen emissions from Erebus volcano, Antarctica. Bull. Volcanol. 74, 2109-2120. doi: 10.1007/s00445-012-0649-2

Naughton, J. J., Lewis, V., Thomas, D., and Finlayson, J. B. (1975). Fume compositions found at various stages of activity at Kilauea Volcano, Hawaii, J. Geophys. Res. 80, 2963-2966. doi: 10.1029/JC080i021p0 2963

Oppenheimer, C., Fischer, T. P., and Scaillet, B. (2014). Volcanic Degassing: Process and Impact. Treatise on Geochemistry, 2nd Edn. Amsterdam: Elsevier, 111-179.

Oppenheimer, C., Keyp, P., Eisele, F., Crawford, J., Huey, G., Tanner, D., et al. (2010). Atmospheric chemistry of an Antarctic volcanic plume. J. Geophys. Res. 115:D04303. doi: 10.1029/2009JD011910

Oppenheimer, C., and Kyle, P. R. (2008). Probing the magma plumbing of Erebus volcano, Antarctica, by open-path FTIR spectroscopy of gas emissions. J. Volcanol. Geotherm. Res. 177, 743-754. doi: 10.1016/j.jvolgeores.2007. 08.022

Oppenheimer, C., Scaillet, B., Woods, A., Sutton, J. A., Elias, T., and Moussallam, Y. (2018). Influence of eruptive style on volcanic gas emission chemistry and temperature. Nat. Geosci. 11, 678-681. doi: 10.1038/s41561-018-0194-5

Ravishankara, A. R., Wine, P. H., Wells, J. R., and Thompson, R. L. (1985). Kinetic study of the reaction of $\mathrm{OH}$ with $\mathrm{HCl}$ from 240-1055 K. Int. J. Chem. Kinet. 17, 1281-1297. doi: 10.1002/kin.550171206

Roberts, T. J., Braban, C. F., Martin, R. S., Oppenheimer, C., Adams, J. W., Cox, R. A., et al. (2009). Modelling reactive halogen formation and ozone depletion in volcanic plumes. Chem. Geol. 263, 151-163. doi: 10.1016/j.chemgeo.2008. 11.012
Roberts, T. J., Braban, C. F., Oppenheimer, C., Martin, R. S., Freshwater, R. A., Dawson, D. H., et al. (2012). Electrochemical sensing of volcanic gases. Chem. Geol. 332-333, 74-91. doi: 10.1016/j.chemgeo.2012.08.027

Roberts, T. J., Lurton, T., Giudice, G., Liuzzo, M., Aiuppa, A., Coltelli, M., et al. (2017). Validation of a novel Multi-Gas sensor for volcanic $\mathrm{HCl}$ alongside $\mathrm{H} 2 \mathrm{~S}$ and SO2 at Mt. Etna. Bull. Volcanol. 79:36.

Roberts, T. J., Martin, R. S., and Jourdain, L. (2014). Reactive halogen chemistry in Mt Etna's volcanic plume: the influence of total $\mathrm{Br}$, high temperature processing, aerosol loading and plume-air mixing (volcanic emissions flux). Atmos. Chem. Phys. 14, 11201-11219. doi: 10.5194/acp-14-11201-12014

Roberts, T. J., Vignelles, D., Liuzzo, M., Giudice, G., Aiuppa, A., Coltelli, M., et al. (2018). The primary volcanic aerosol emission from Mt Etna: size-resolved particles with SO2 and role in plume reactive halogen chemistry. Geochim. Cosmochim. Acta 222, 74-93. doi: 10.1016/j.gca.2017.09.040

Rose, W. I., Millard, G. A., Mather, T. A., Hunton, D. E., Anderson, B., Oppenheimer, C., et al. (2006). Atmospheric chemistry of a 33-34 hour old volcanic cloud from Hekla Volcano (Iceland): insights from direct sampling and the application of chemical box modeling. J. Geophys. Res. Atmos. 111:D20206. doi: 10.1029/2005JD006872

Sahyoun, M., Freney, E., Brito, J., Duplissy, J., Gouhier, M., Colomb, A., et al. (2019). Evidence of new particle formation within Etna and Stromboli volcanic plumes and its parameterization from airborne in-situ measurements. J. Geophys. Res. Atmos. 124, 5650-5668. doi: 10.1029/2018JD028882

Schumann, U., Weinzierl, B., Reitebuch, O., Schlager, H., Miniki, A., Forster, C., et al. (2011). Airborne observations of the Eyjafjalla volcano ash cloud over Europe during air space closure in April and May 2010. Atmos. Chem. Phys. 11, 2245-2279. doi: 10.5194/acp-11-2245-2011

Surl, L., Donohoue, D., Aiuppa, A., Bobrowski, N., and von Glasow, R. (2015). Quantification of the depletion of ozone in the plume of Mt Etna. Atmos. Chem. Phys. 15, 2613-2628. doi: 10.5194/acp-15-2613-2015

Vance, A., McGonigle, A. J. S., Aiuppa, A., Stith, J. L., Turnbull, K., and von Glasow, R. (2010). Ozone depletion in tropospheric volcanic plumes. Geophys. Res. Lett. 37:L22802. doi: 10.1029/2010GL044997

Voigt, C., Jessberge, P., Jurkat, T., Kaufmann, S., Baumann, R., Schlager, H., et al. (2014). Evolution of $\mathrm{CO} 2, \mathrm{SO} 2, \mathrm{HCl}$ and $\mathrm{HNO} 3$ in the volcanic plumes from Etna. Geophys. Res. Lett. 41, 2196-2203. doi: 10.1002/2013GL058974

von Glasow, R. (2010). Atmospheric chemistry in volcanic plumes. Proc. Nat. Acad. Sci. U.S.A. 107, 6594-6599. doi: 10.1073/pnas.0913164107

Woodhouse, M. J., Hogg, A. J., Philips, J. C., and Sparks, R. S. J. (2013). Interaction between volcanic plumes and wind during the 2010 Eyjafjallajökull eruption, Iceland. J. Geophys. Res. 118, 92-109. doi: 10.1029/2012JB009592

Zelenski, M., Taran, Y., and Galle, B. (2015). High emission rate of sulfuric acid from Bezymianny volcano, Kamchatka. Geophys. Res. Lett. 42, 7005-7013. doi: $10.1002 / 2015$ GL065340

Conflict of Interest Statement: The authors declare that the research was conducted in the absence of any commercial or financial relationships that could be construed as a potential conflict of interest.

The handling Editor declared a past co-authorship with one of the authors, TR.

Copyright (c) 2019 Roberts, Dayma and Oppenheimer. This is an open-access article distributed under the terms of the Creative Commons Attribution License (CC BY). The use, distribution or reproduction in other forums is permitted, provided the original author(s) and the copyright owner(s) are credited and that the original publication in this journal is cited, in accordance with accepted academic practice. No use, distribution or reproduction is permitted which does not comply with these terms. 